\title{
41. AMAZON FAN SEDIMENTATION: THE RELATIONSHIP TO EQUATORIAL CLIMATE CHANGE, CONTINENTAL DENUDATION, AND SEA-LEVEL FLUCTUATIONS ${ }^{1}$
}

\author{
Roger D. Flood ${ }^{2}$ and David J.W. Piper ${ }^{3}$
}

\begin{abstract}
Seventeen sites on the Amazon Fan were drilled during Leg 155. Although the oldest recovered sediment dates from isotopic Stage 8 ( $\sim 0.25 \mathrm{Ma})$, our sampling concentrated on the last glacial cycle. Sites were correlated by seismic reflection profiles, paleomagnetic orientation and intensity, stable isotopes of planktonic foraminifers, and biostratigraphic methods. The Amazon Fan aggraded during lowstands of sea level and switched depocenters following major highstands, when pelagic and/or hemipelagic calcareous clay was deposited across the fan. Only one distributary channel was active at any one time, although spillover of turbidity currents led to channel-related deposition on abandoned levees. Depositional rates on the levees of active channels reached $25 \mathrm{~m} / \mathrm{k}$.y. Although we have identified the position of the last interglacial (Stage 5) on the fan, we have not yet identified a deposit formed at the initial lowering of sea level at the Stage 4/5 boundary in cores or on seismic profiles. Recovered and logged sediments show that prominent, coarse-grained deposits are present in flat-lying layers that underlie middlefan channels as well as in channels. These coarse layers form units up to $25 \mathrm{~m}$ thick, and were formed following avulsions. These units extend downfan to form the bulk of the lower fan. The existence of coarse, sheet sediment deposits in this overall muddy fan is at odds with the view that significant coarse-grained sediments do not exist in muddy fans. Since leveed channels can transport coarse-grained sediments to the middle and lower fan, separate sedimentary processes are not required to create a sandy lower fan and channel-levee systems on the upper and middle fan: these deposits are contemporaneous and form whenever the fan is active.

The rapidly accumulated sediments contain a high-resolution record of both oceanic and continental paleoclimate that will require much more study. Surface gradients in the ocean are steep, resulting from the complex interaction of saline South Atlantic water and freshwater discharge from the Amazon River. Detrital palynomorphs and phytoliths show that there was only modest cooling and an extension of savannah in the Amazon Basin during the last glacial maximum. The organic matter deposited on the Amazon Fan is broadly similar in composition to the modern Amazon River. The enhanced transport of organic matter to the Amazon Fan when the fan is active reduces the amount of carbon remineralization.

Leg 155 has demonstrated both the feasibility and value of high-resolution drilling on continental margins, for solving paleoenvironmental, sedimentological, and geochemical questions. In particular, we have demonstrated that the sampling of mudrich deep-sea fans can be a practical tool for the sampling of integrated terrestrial and oceanic paleoclimate records; a technique that can be followed in other regions.
\end{abstract}

\section{INTRODUCTION}

Continental margin environments are important repositories of information about the Earth's history. Sediments deposited in this environment, although sometimes difficult to decipher, contain records of sea level, sediment flux to the oceans, ocean circulation, and land and ocean climate. Margin environments are of particular importance because sedimentation rates are usually high (thus allowing for highresolution records), and they are located where environmental gradients are steep and where the marine and terrestrial records interfinger. Interpreting this record requires a detailed understanding of sedimentary processes and distribution patterns.

The study of margin sediments is particularly rewarding in regions of submarine fans. Submarine fans form the largest deep-water sediment bodies on continental margins, and the record of sediment flux to submarine fans can provide important information about the effects of land climate, sea level, and source area tectonic activity. However, our understanding of the growth patterns of submarine fans and of the relative roles of processes internal and external to the fan in creating the sediment body is limited. Many of the materials that

${ }^{1}$ Flood, R.D., Piper, D.J.W., Klaus, A., and Peterson, L.C. (Eds.), 1997. Proc. ODP, Sci. Results, 155: College Station, TX (Ocean Drilling Program).

${ }^{2}$ Marine Sciences Research Center, State University of New York, Stony Brook, NY 11794-5000, U.S.A.rflood@sunsyb.edu

${ }^{3}$ Atlantic Geoscience Centre, Geological Survey of Canada (Atlantic), Bedford Institute of Oceanography, P.O. Box 1006, Dartmouth, Nova Scotia B2Y 4A2, Canada. accumulate on fans originate on land, and their composition (both inorganic and organic) contains important information about the climate and erosional history of the source area. Several sedimentary environments may be present at any one time in fan deposits, and each environment can provide a different record of paleoclimate. During marine lowstands, the levee of an active channel contains materials delivered by rivers to the continental slope with minimal time delay. The biota of the ocean and associated organic materials can be preserved in fan environments where downslope transport is minimized, such as local topographic highs including abandoned levee crests. Sedimentation rates in these environments are, nevertheless, higher than in pelagic environments, so that an expanded section is expected, but age control is possible.

Normal piston cores penetrate only the upper $10 \mathrm{~m}$ or so of thick sedimentary deposits typical of submarine fans and thus sample only the most recent time intervals. As a result, our overall understanding of the sedimentary facies associated with seismic and morphological units, the age of these units and their relationships to one another, and the climatic record preserved in their sediments remain poor. Deep, continuous sampling in morphologically well-defined areas is required to make significant progress toward understanding the depositional patterns and growth of deep-sea fans. This information can then be applied to interpreting modern continental margins and ancient turbidite basins.

The Amazon Fan, at the mouth of the Amazon River, provided an opportunity to investigate a large muddy fan and the stratigraphic and climatic records that it contains. The Amazon Fan is one of the largest modern submarine fans and forms a significant proportion of the con- 
tinental margin off northeastern Brazil (Fig. 1). The fan contains much of the material eroded from the continent within the Amazon drainage basin. Large fans, such as the Amazon, Mississippi, Indus, and Bengal fans, are formed by the long-term localized input of fluvial sediments moderated by glacio-eustatic sea-level fluctuations, climate change, and tectonic activity.

This study focuses on the development of the Amazon Fan during the last few late Quaternary glacial-interglacial climate cycles characterized by frequent, high-amplitude sea-level fluctuations. This focus is desirable because a detailed global sea-level record is available for this time interval, especially during the last glacial-interglacial cycle (isotopic Stages 1-5), and is necessary because the fan deposits are thick. However, the architectural elements of the Amazon Fan that developed during the latest climatic cycle appear similar to those of muddy fans known to have deposited during earlier intervals under different sea-level patterns (e.g., Pleistocene-Pliocene Gulf of Mexico, Weimer, 1990; Cretaceous California, Nilsen et al., 1994), thus the results of this study are expected to apply to some extent in a number of areas and time intervals.

The record of land climate in equatorial South America, the source region of the Amazon River, is of critical importance to our understanding of Quaternary climatic history. Equatorial regions play a pivotal role in the atmospheric transport of heat to higher latitudes. Land climate records in such regions are short. For the Amazon Basin, few records extend back into the last glacial maximum (LGM), so climate conditions at that time are poorly known. Materials (organic and inorganic) transported by the Amazon River are deposited on the Amazon Fan during times of lowered sea level and thus potentially provide a detailed record of land climate.

The Amazon Fan also underlies the western tropical Atlantic water masses. These water masses and their circulation patterns are particularly important in terms of ocean dynamics and interocean heat transfer (Fig. 2). During glacial times, equatorial circulation patterns may have been different because of, for example, changing wind patterns or narrower shelves. Reduced flow of the North Brazil Coastal Current (NBCC) across the equator would reduce cross-equatorial oceanic heat and salt transport, both of which are important components of the global ocean circulation pattern. If this were the case, then circulation patterns of the glacial western tropical Atlantic could at times have been very different from the modern-day circulation regime. Understanding the changes in ocean properties and ocean circulation that have occurred will contribute to the understanding of global circulation dynamics.

Seventeen sites were drilled on the Amazon Fan during Leg 155 (Fig. 1) to meet four main objectives (Flood, Piper, Klaus, et al., 1995; Shipboard Scientific Party, 1995a):

1. To determine the relationship between the development of fan deposits, sea-level change, and climatic and possibly tectonic changes in the Amazon Basin.

2. To determine the sediment lithologies characteristic of distinctive acoustic facies and sedimentary processes.

3. To use the stratigraphic record of the Amazon Fan to better understand climatic change within the Amazon drainage basin and the overlying western equatorial Atlantic.

4. To characterize and understand the nature, origin, and early diagenesis of organic carbon present in different fan units.

In this paper, we discuss the results of Leg 155 in terms of these objectives. Others papers in this volume provide a fuller discussion of results and their implications: our aim is to provide a useful summary of these results and to explore linkages between the various studies.

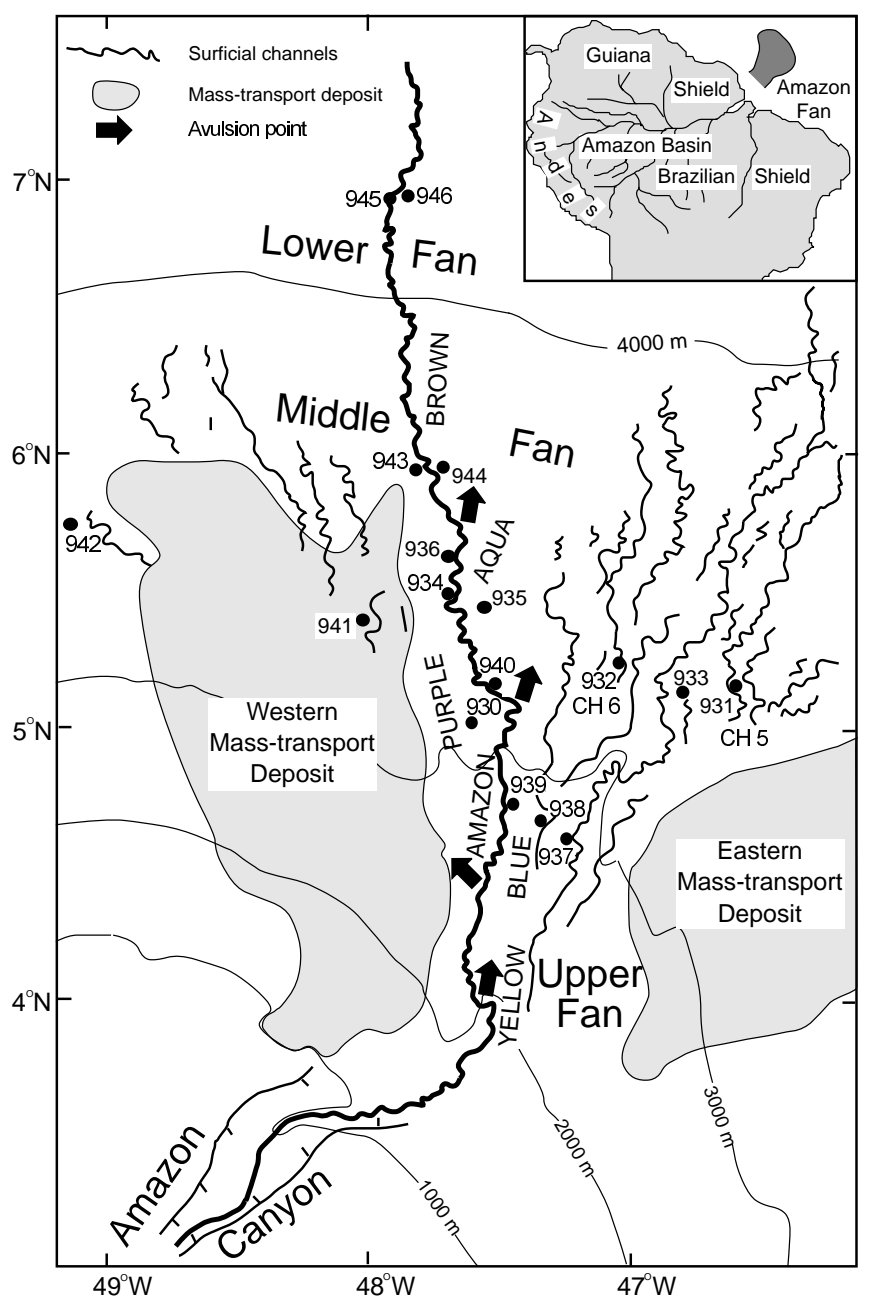

Figure 1. Map of the Amazon Fan showing the location of sites and names of surficial channels of the Upper Levee Complex. Note that the heavy line is the Amazon Channel. The Yellow, Blue, Purple, Aqua, and Brown Channels are located about where their names are shown (figure modified from Damuth et al., 1988, and Manley and Flood, 1988).

\section{RELATIONSHIP OF FAN GROWTH TO SEA LEVEL AND CLIMATE}

\section{Objectives}

The first objective of Leg 155 was to determine the relationship between the development of fan deposits, sea-level change, climatic and possibly tectonic changes in the Amazon Basin. The objective addresses a long-standing sedimentological question: to what extent do the major sedimentary bodies, including deep-sea fans, evolve through autocyclic processes, and what is the relative importance of sediment supply (controlled by climate and tectonics) and sea-level change in the development of sediment facies (e.g., Stow et al., 1985)? We also wished to test, in a general way, the conceptual sequence stratigraphic models that have evolved through a series of papers by P.R. Vail, co-workers, and others (e.g., Vail et al., 1977; Posamentier and Vail, 1988; Vail et al., 1991; Posamentier and Allen, 1993); in particular, the proposition that a coarser grained deposit, 
A
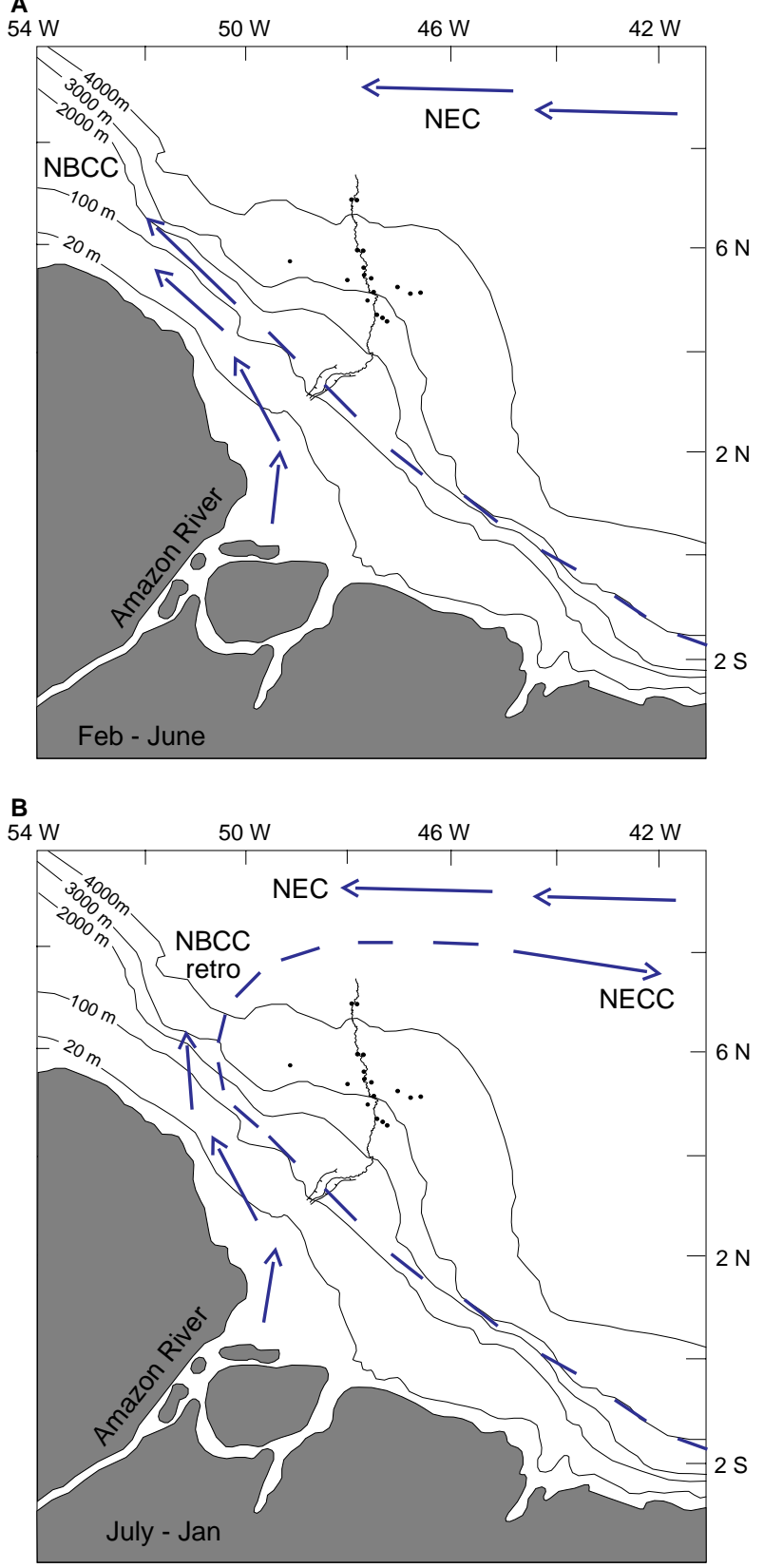

Figure 2. Schematic representation of the present ocean circulation over the Amazon Fan. NBCC = North Brazil Coastal Current; NEC $=$ North Equatorial Current; $\mathrm{NECC}=$ North Equatorial Counter Current; retro = retroflection of NBCC; small dots show locations of Leg 155 sites. A. Surface circulation from February to June. B. Surface circulation from July to January.

some times called a "basin floor fan," formed at sea-level falls or lowstands is downlapped by a finer grained deposit, sometimes called a "slope fan," formed later, perhaps during sea-level rise. In addition, several authors (e.g., Posamentier and Allen, 1993; Reading and Richards, 1994) have suggested, based on systems tracks analysis, that large muddy fans, such as the Amazon Fan, generally should not contain sand-rich layers. However, autocyclic processes may play an important role in the development of sand layers in muddy fans (Flood et al., 1991) a suggestion testable by drilling.

\section{Relationship to Large-Scale Sea-Level Fluctuations}

Growth patterns of major deep-sea fans are well-known from seismic studies (e.g., Weimer, 1989, 1990; Droz and Bellaiche, 1985), but with the exception of the Mississippi Fan, precise chronologic control is lacking that will allow major architectural elements to be related to changes in sea level. Leg 155 provided such chronologic control on the Amazon Fan.

The Amazon Fan has aggraded principally by the deposition of thick channel-levee deposits from turbidity currents (Manley and Flood, 1988). Periodic channel avulsion has resulted in the deposition of a series of overlapping channel-levee deposits downfan from a canyon system. Previous workers on the Amazon Fan (Damuth et al., 1983; Manley and Flood, 1988) have assigned names to all the recognized channel-levee systems as follows (Figs. 1, 3; see also Flood et al., 1995 and Shipboard Scientific Party 1995a for a description of fan stratigraphy).

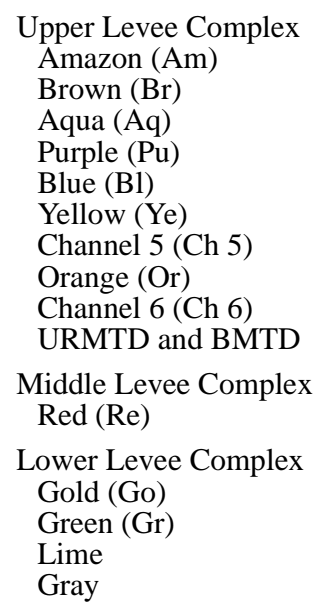

Bottom Levee Complex

Upstream from any particular avulsion point, two successive channel-levee systems may follow the same path. Individual channellevee units appear to group into larger levee complexes: the Upper, Middle, Lower, and Bottom Levee Complexes (Fig. 3). Levee complexes occupy geographically distinct areas of the fan and are commonly separated from each other by mass-transport deposits (MTDs) and flat-lying seismic reflections.

Previous piston core studies have shown that the Amazon Fan aggraded and built channel levees during the late Pleistocene, but that by the mid-Holocene, rising sea level had ended significant crossshelf transport of Amazon sediment, which was advected northward along the South American coast by the North Brazil Coastal Current. Hemipelagic mud with $10 \%-45 \% \mathrm{CaCO}_{3}$ accumulated across the fan during the Holocene highstand of sea level. Detailed foraminifer study at Site 934 (adjacent to the most recently active fan channel; Shipboard Scientific Party, 1995b) showed that calcareous mud first accumulated $\sim 9 \mathrm{ka}$, when the sea level was probably $\sim 30 \mathrm{~m}$ below present sea level and the proportion of calcium carbonate was highest from $\sim 6 \mathrm{ka}$ to the present time, the time of the highest Holocene sea level off Brazil (Farrell and Clark, 1976; Fairbanks, 1989). 


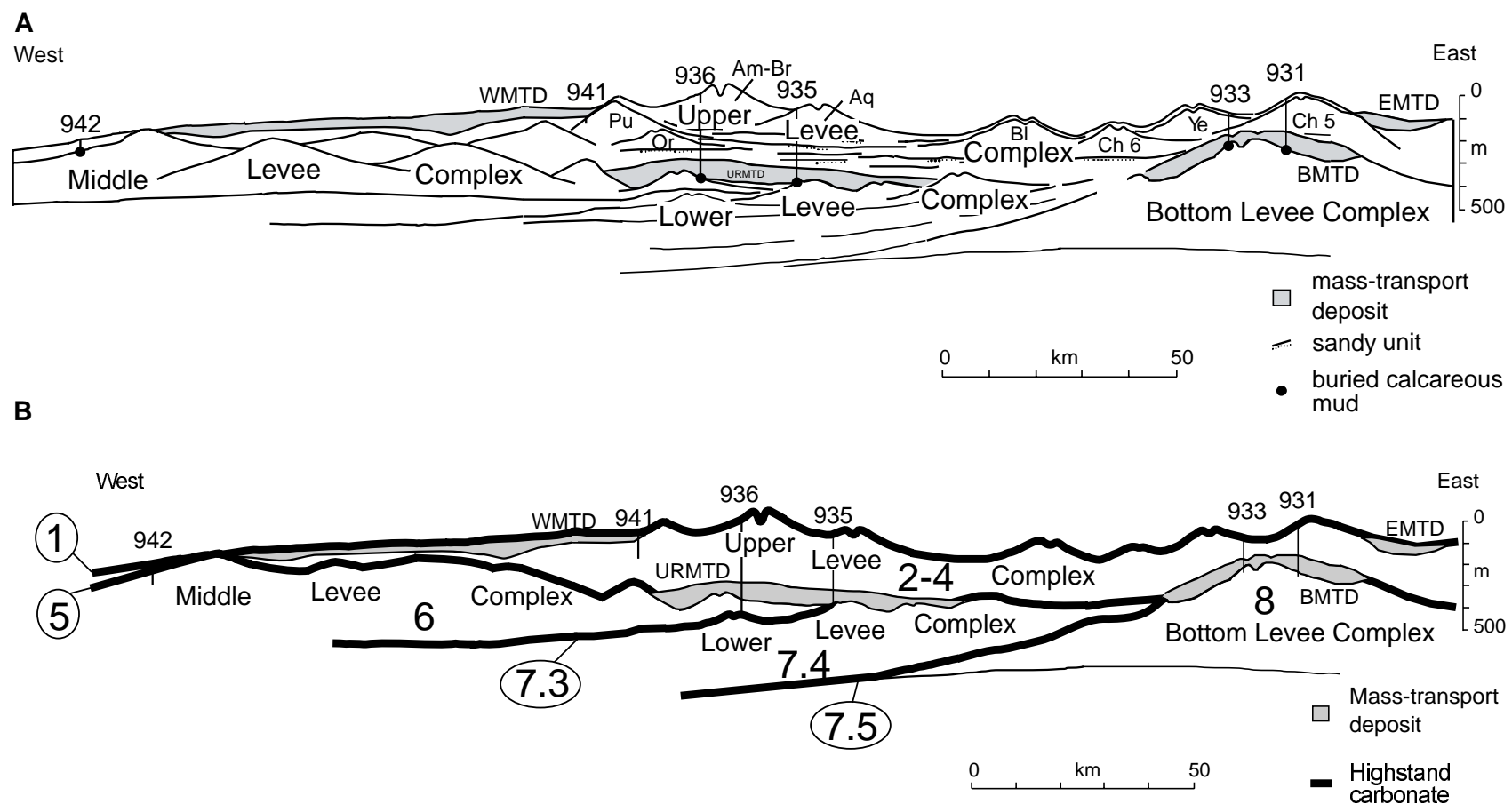

Figure 3. Schematic cross section of the Amazon Fan through selected ODP sites showing (A) the major levee complexes, MTDs, and buried calcareous muds, and (B) the predicted location of highstand carbonate units (from Piper et al., Chapter 39, this volume). Names of channel-levee systems (Ch 6, Ch 5, Or, Ye, Bl, $\mathrm{Pu}, \mathrm{Aq}$, and $\mathrm{Am}-\mathrm{Br}$ ) are summarized on page 3, this chapter. Stages and substages are given in large, bold numbers.

Lithologically similar buried carbonate-rich muds overlie the Middle, Lower, and Bottom Levee Complexes. Where recovery was good, these carbonate-rich muds pass down gradually into bioturbated mud and then levee mud with silt laminae, in a manner analogous to the transition from Holocene calcareous mud to latest Pleistocene levee deposits. However, no carbonate-rich mud is identified overlying individual channel-levee systems within the levee complexes, suggesting that multiple channel-levee systems have formed during a single sea-level lowstand. The buried carbonate-rich muds contain interglacial microfossil assemblages (Maslin and Mikkelsen, this volume). At Site 942, oxygen isotope stratigraphy clearly shows that carbonate-rich muds were deposited during marine highstands of Substages 5a, 5c, and 5e (Showers et al., this volume). At Site 946, the presence of the Blake paleomagnetic event in a carbonate-rich mud (Cisowski and Hall, this volume) also demonstrates the presence of this lithology during a Stage 5 highstand. These Stage 5 calcareous muds overlie the Middle Levee Complex (Fig 4). Calcareous muds overlying the Lower Levee Complex are assigned to isotopic Substage 7.3 and those overlying the Bottom Levee Complex to Substage 7.5 (Piper et al., Chapter 39, this volume).

The geographic distribution of each levee complex (e.g., Fig. 1 in map view for the Upper Levee Complex and Fig. 3 in cross-section) and limited seismic data (Manley and Flood, 1988) indicate that the main dispersal point on the upper continental slope (corresponding to the Amazon Canyon for the Upper Levee Complex) was different for each levee complex.

Analysis of sediment recovered during Leg 155 has demonstrated that each major architectural element of the Amazon Fan, a levee complex built of a number of individual channel-levee systems, developed during a major lowstand of sea level. However, major lowstands for the Pleistocene may not precisely correlate with the standard isotope stages, because two levee complexes (Bottom and Lower) may have formed during Stage 7. Only highstands of sea level that rose to within $\sim 30 \mathrm{~m}$ of present sea level (shelf-edge water depth of $\sim 50 \mathrm{~m}$ ) appear to have been sufficient to end cross-shelf sediment transport from the Amazon delta system to the fan, although northwestward-flowing coastal currents may also play a role in diverting Amazon River sediment from the slope from the shelf. During the sea-level fall that followed such a major transgression, the principal upper slope pathway for sediment may have been re-established at a different site, probably as a result of the fortuitous position of the principal distributary mouth during regression. The magnitude of sea-level fall needed to initiate deep-sea fan deposition in the Amazon system is less clearly resolved, although sea-level falls of $\sim 25 \mathrm{~m}$ (shelf-edge water depths of $\sim 55 \mathrm{~m}$ ) apparently did not initiate fan deposition during Stage 5 (see later discussion of Stage 5 turbidites at Site 942).

In the areas drilled by Leg 155 , levee complexes tend to be separated by large MTDs, which makes the levee complexes distinctive features on seismic records. Although major MTDs appear to correlate with times of falling or maximum lowstand of sea-level (Piper et al., Chapter 6, this volume), major MTDs do not appear to have formed during every sea-level lowstand, and the upper boundaries of levee complexes (which correspond to sea-level highstands) can be traced laterally into undrilled regions where no MTD is present to separate the levee complexes (Fig. 3).

\section{Timing of Individual Channel-Levee Systems}

If the major "Levee Complexes" are controlled by major sea-level changes, can there also be a sea-level influence on the development of individual channel-levee systems? Previous workers have inferred from seismic reflection profiles that only one channel system was active at any one time (Damuth et al., 1983; Manley and Flood, 1988). Pirmez and Flood (1995) have argued that the periodic avulsion of channel systems is an autocyclic process related in part to the failure 
of levee flanks, and probably strongly influenced by evolution of channel gradient.

Precise correlation of sites on the Upper Levee Complex has been achieved by means of oxygen isotopes, paleomagnetic variation, and changes in magnetic susceptibility (Piper et al., Chapter 39, this volume). While site-to-site correlation is quite good, detailed age models are still preliminary, and are based principally on the correlation of paleomagnetic intensity with other dated sequences (Cisowski and Hall, this volume). These correlations confirm that any one time, only one channel system in the Upper Levee Complex was active, in the sense of being a continuous conduit for sandy turbidity currents. Channels appear to have been conduits for muddy turbidity currents, presumably from spillover of tops of turbidity currents at the avulsion point, following abandonment (Piper et al., Chapter 39, this volume).

Figure 5 shows when the various channel-levee systems of the Upper Levee Complex were active and correlates this activity with an independently derived eustatic sea level during isotope Stages 2-4 (see Flood, Piper, Klaus, et al. [1995] for a discussion of this sea level curve). Dating of past sea-level high- and lowstands prior to the LGM at $\sim 20 \mathrm{ka}$. is not sufficiently precise to correlate changes in distributary pattern with changes in sea level. Despite the minor uncertainties in the timing of both eustatic sea-level changes and channel-levee system activity, there is no evidence for a link between the two. Our sampling of channel-levee systems of the deeper levee complexes is not sufficient to continue this detailed correlation to older time intervals, but their channel-levee systems are definitely older than Stage 5 (125 ka).

Within the levee of a single channel system, for example, Brown at Site 935 or Aqua at Site 940, there are considerable variations in the abundance and thickness of silt laminae. Oxygen isotopes allow precise correlation of some of these intervals between cores (e.g., 30 meters below sea floor [mbsf] at Site 935, which corresponds to 28 mbsf at Site 936 and to 42 mbsf at Site 939). These variations may be the result of autocyclic changes in the depth of the turbidity current channel (so that varying amounts of coarse sediment overspill the levees), as argued by Pirmez and Flood (1995). However, the recognition that abandoned channels continue to act as pathways for overbanking turbidity currents suggests that very substantial and perhaps reversible changes in channel depth would be needed to produce the observed variation in the abundance of silt laminae. Alternatively, these variations may result from differences in the river sediment load or character of turbidity currents as a result of unrecognized mi-

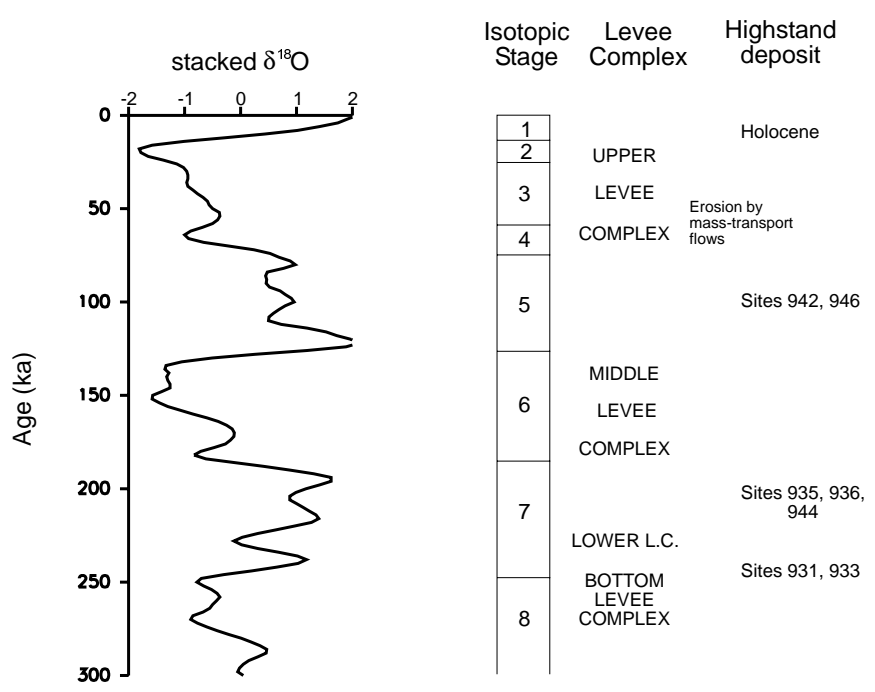

Figure 4. Schematic sea-level curve (isotope curve of Imbrie et al., 1984) showing the relationship to the major architectural features of the Amazon Fan. nor sea-level changes, climatic changes, changes in the delta at the mouth of the glacial Amazon River, or changes in coastal current strength.

Several factors could be responsible for small, unrecognized sealevel changes in the vicinity of the Amazon Fan. Driscoll and Karner (1994) suggest that crustal loading by Amazon Fan sediments could result in localized uplift affecting both local sea level and river gradients near the coast and lead to a reduction in sediment supply to the fan. Detailed modeling of crustal loading and coastal uplift will be needed to determine the timing of these events.

Small-scale, climate-related isostatic changes in sea level may also be possible, for example, as related to high-latitude Heinrich events (Maslin et al., this volume). In general, intervals of heavy oxygen isotope peaks in planktonic foraminifers correspond to intervals of more abundant silt laminae in levee sections (Fig. 6). We do not currently understand the significance of such heavy peaks. Some may correspond to global peaks related to global ice volumes and hence sea level: for example, peak $h c$ in Figure 6 appears to correspond to the LGM lowstand of sea level (Stage 2.2). Others, such as the peak $h b$, appear to have an origin in changing surface circulation, and Maslin et al. (this volume) postulate that they may be related to climatic changes associated with high-latitude Heinrich (ice melting) events, and thus they probably result in rapid rises of sea level (of the order of 1-2 m). In the Amazon Basin, Heinrich events may be expressed by incursions of saline waters above the Amazon Fan as well as by increased precipitation, leading to a greater discharge of silty sediment from the Amazon River. If the heavy planktonic isotope events are associated with Heinrich events, we see no obvious sedimentological effects of a rapid sea-level rise because sediment flux to the fan appears to increase during heavy events rather than decrease.

The base of a levee system, marking a change in channel pattern, is best defined in sections where the levee overlies high-amplitude reflection packets (HARPs; Fig. 7). In such circumstances, isotopic data across the base of the levee system are sparse. The correlation of levee systems between holes (Piper et al., Chapter 39, this volume) suggests that some levee systems were initiated at times of heavy

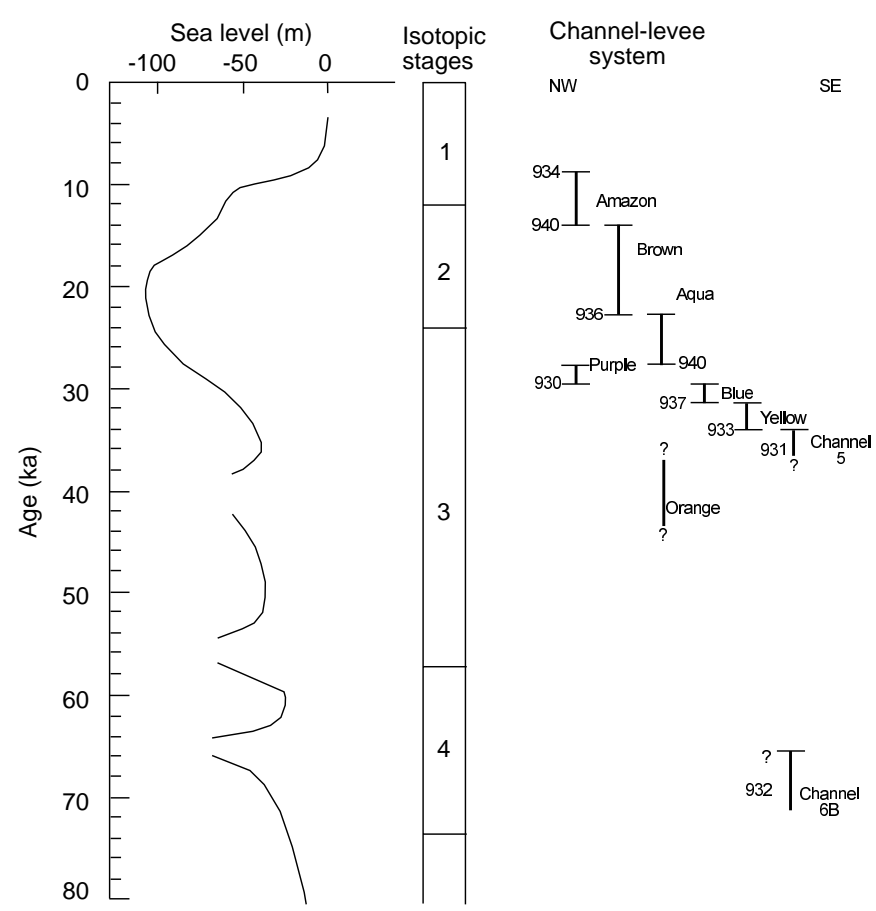

Figure 5. Sea-level curve (from Flood, Piper, Klaus, et al., 1995) showing isotopic stages and the timing of channel-levee systems in the past 50 k.y. 

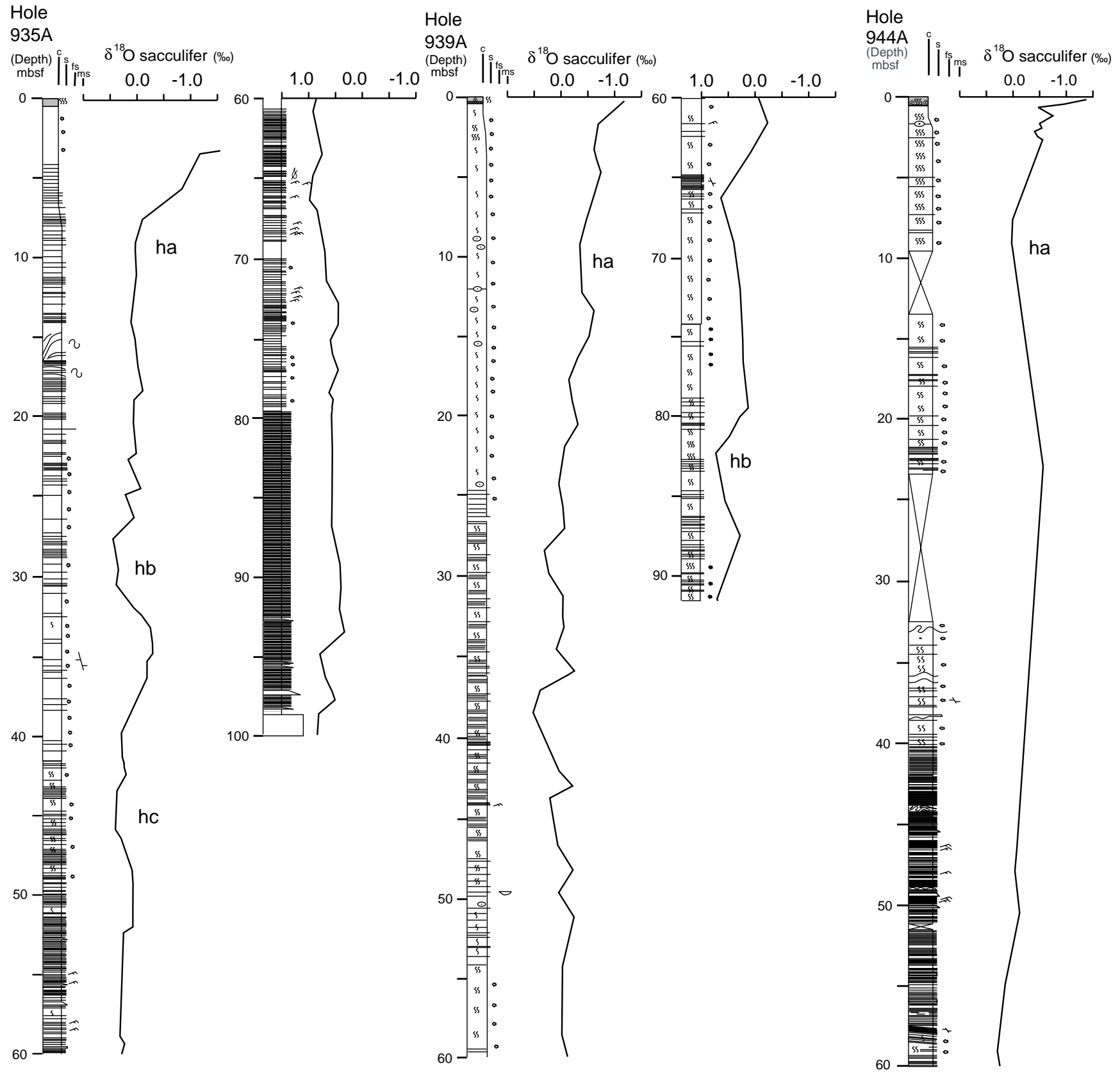

Figure 6. Downcore plot for Sites 935, 939, and 944 of $\delta^{18} \mathrm{O}$ (G. sacculifer) against a visual log of silt laminae in levee sediment. $h a, h b$, and $h c=$ heavy isotopic events as discussed in Piper et al. (Chapter 39, this volume). 
A

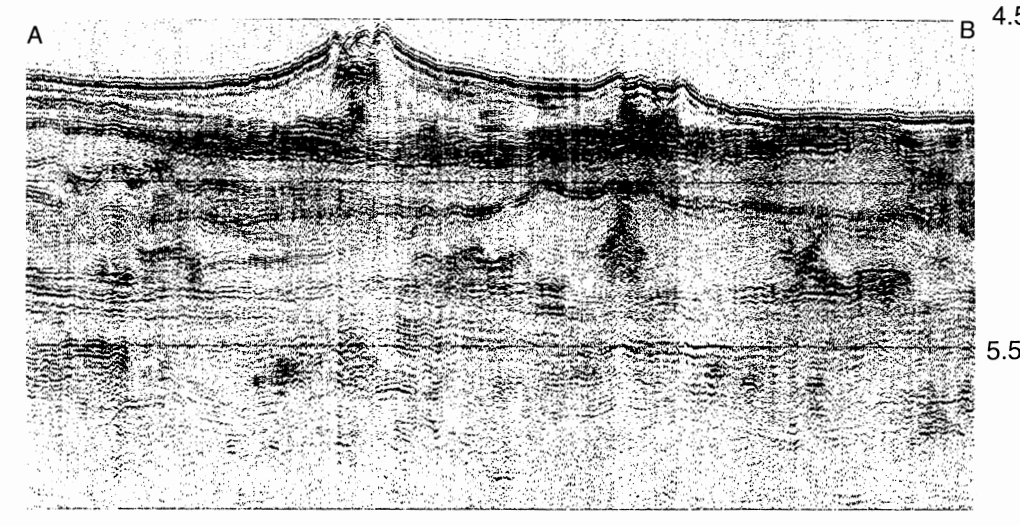

W

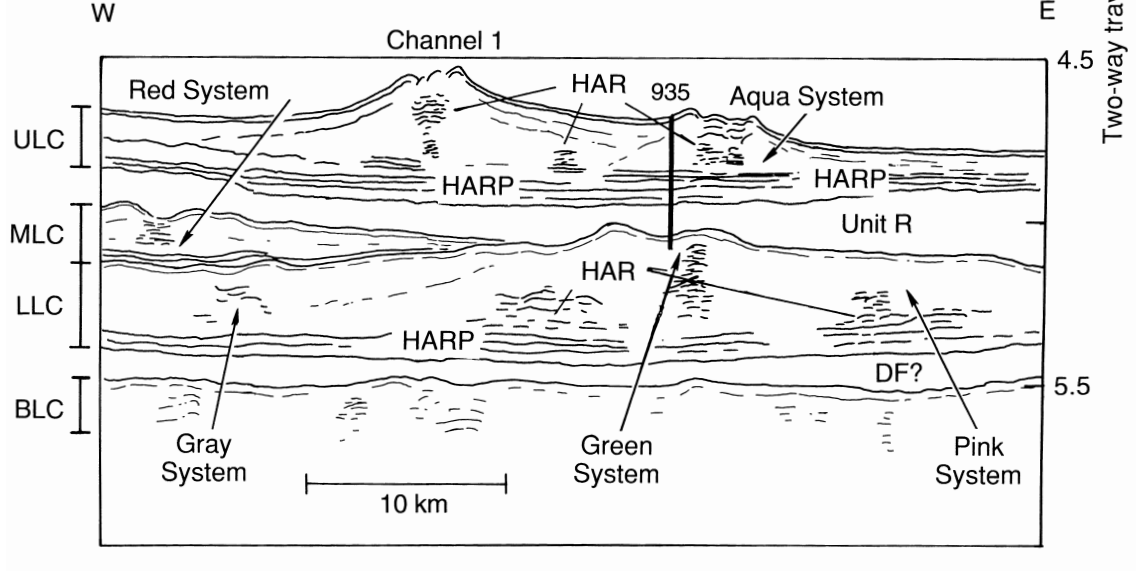

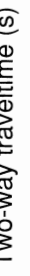

Figure 7. A. Representative seismic profile from the middle Amazon Fan showing seismic facies in the vicinity of Site 935. ULC $=$ Upper Levee Complex; MLC $=$ Middle Levee Complex $;$ LLC $=$ Lower Levee Complex; $\mathrm{BLC}=$ Bottom Levee Complex; $\mathrm{DF}=$ mass transport deposit; HAR = high-amplitude reflections; HARP $=$ high-amplitude reflection packet. planktonic isotope peaks and enhanced silt supply (e.g., base of Amazon system at 40-45 mbsf at Site 939 and 57 mbsf at Site 940; base of Brown at $72 \mathrm{mbsf}$ at Site 936 and $\sim 60 \mathrm{mbsf}$ at Site 935; base of Aqua at $115 \mathrm{mbsf}$ at Site 935). These intervals correspond approximately to intervals with more highly negative $\delta^{13} \mathrm{C}$ (Schneider et al., this volume; Maslin et al., this volume). On the other hand, the base of the Blue system in Site 938 and the base of the Yellow system in Site 933 both correspond to light peaks in the oxygen isotopic curves.

Taken all together, these observations may mean that the avulsion process is primarily an autocyclic process of leveed fan channels, because the timing of avulsions does not appear to be uniformly tied to any particular climatic or sea-level event. Avulsions may still be initiated by particular events, such as levee failure associated with enhanced sediment supply to certain sections of the channel. However, the location and timing of such events (at $~ 3-$ to 10-k.y. intervals on the Amazon Fan) appears to be related to natural variability in sediment transport on the fan rather than to outside factors.

\section{Stage 5 (Highstand) Turbidite Deposition: Site 942}

Analysis of sediment sequences and oxygen isotopic studies show that deposition on the fan is cut off during times when sea level is highest, such as at the present time. The sediments deposited at these times are calcareous, have a light isotopic character, and have an interglacial fauna and flora. However, oxygen isotope records and sealevel curves (Figs. 4, 5) suggest that the sea level was not uniformly at its highest stage during interglacial periods such as during isotope Stage 5, but it varied within a range of $\sim 25 \mathrm{~m}$ and a period of $\sim 20 \mathrm{k} . \mathrm{y}$. The sediment record recovered from Site 942, located on perhaps the most recent Stage 6 (Middle Levee Complex) on the western side of the fan, reveals a record of turbidite sedimentation during Stage 5 that is in part related to these small, interglacial sea-level fluctuations.
Shipboard descriptions suggest that the relatively thin $(\sim 30 \mathrm{~m}$ thick; thin compared to a typical levee deposit) turbidite section at Site 942 developed in isotopic Stage 5 is quite different from turbidite sections elsewhere on the Amazon Fan (Shipboard Scientific Party, 1995d). The turbidites in this section consist of cleaner sands than any other turbidites on the Amazon Fan, and, as a result, they are somewhat coarser than those typical of levee deposits. Detailed correlation with the age model developed from oxygen isotope stratigraphy (Fig. 8; Showers et al., this volume; Schneider et al., this volume) shows that turbidites are most frequent at intermediate stands of sea level, perhaps immediately following the three carbonate-rich Stage 5 sea-level highs, when shelf-edge water depths would have been in the range of 70-55 m, 10-20 m below present sea level. This terrigenous input results in an overall Stage 5 sedimentation rate of $\sim 50$ $\mathrm{cm} / \mathrm{k}$.y., with values over $100 \mathrm{~cm} / \mathrm{k} . \mathrm{y}$. In contrast, the 942 sediment record during the Stages 4, 3, and 2 lowstand is only $\sim 25 \mathrm{~m}$ thick, much thinner than at all other fan sites, suggesting that little sediment reached this site during the most recent lowstand. Sedimentation rates are relatively low during Stages 4,2 , and most of $2(\sim 30 \mathrm{~cm} /$ k.y.), but increase slightly at the end of Stage 2 and early in Stage 1 $(\sim 50 \mathrm{~cm} / \mathrm{k} . \mathrm{y}$.$) , before dropping to low modern highstand values (\sim 6$ cm/k.y.).

This apparently anomalous sediment record is consistent with likely sediment processes active on the shelf and fan and suggests the variety of sediment sequences possible within a fan setting. The Stage 5 turbidites appear to be derived from reworked outer shelf sands that are shed from the shelf (perhaps preferentially during storm resuspension and most likely enhanced by relatively small sealevel falls; see also Posamentier et al., 1991). Highstand turbidite deposition at this site may also be enhanced by the location of Site 942 adjacent to a fan channel active during Stage 6, especially while the canyon associated with this older channel acted to intercept sands being transported on the shelf. During the larger Stages 2-4 sea-level 
Figure 7 (continued). B. Block diagram illustrating the development of a new channel-levee system (and associated HARPs) following an avulsion event (after Flood et al., 1991).

fall, the new Amazon canyon developed $\sim 100 \mathrm{~km}$ southeast of this site, resulting in relatively little sediment reaching this site. The increased sedimentation rate at the end of Stage 2 and early in Stage 1 may result from northward current-related sediment transport of sediment that escaped the river/canyon system during the last sea-level rise.

\section{Sequence Stratigraphy and Sea-Level Change}

A multistep approach can be used to relate depositional patterns on the Amazon Fan to sea-level change, and thus to possible sequence stratigraphic models. The first step is to sample seismic units on the fan, focusing on the muddier parts built by channel-levee systems where the best age control is expected, to determine the facies and ages of those units. The second step is to compare the ages of those units with a late Pleistocene sea-level curve to determine in what part of the sea-level cycle they were formed. The third step is to examine the cored section and the seismic profiles, now tied to the sea-level curve, to determine where the sediments deposited during different portions of the global sea-level curve should lie (i.e., fall, lowstand, rise, highstand; Fig. 9). The final step is to evaluate the seismic and cored sediment facies to determine whether there are systematic variations during a sea-level cycle in this deep-water system similar to those generally predicted. This can be done in a preliminary fashion with the data in hand, but additional studies are anticipated.

A number of sequence stratigraphic models have been presented that include deep-water sediment deposits, often termed fans, and these models are rapidly evolving as new data become available. Because of rapid change in this field, a detailed stratigraphic discussion will not be undertaken; instead, we will focus on a general discussion of depositional patterns and facies. Although we recognize that some variability is to be expected from a generalized sequence-stratigraphic approach based on a number of factors, the Amazon Fan is often cited as a fine-grained end-member fan deposit (e.g., Vail et al., 1991; Posamentier and Allen, 1993; Reading and Richards, 1994), and thus it is reasonable to compare our results with the generalized models. We also recognize that our age dating, sample base, and seismic coverage are not exhaustive, especially on the lower fan, and that unsampled and unrecognized deposits may exist.

Ages have been determined for most of the sampled units, especially for the channel-levee systems in the Upper Levee Complex, and with less resolution in the Middle, Lower, and Bottom Levee Complexes, as well as for major sea-level highstands and MTDs (Piper et al., Chapters 6 and 39, this volume; Mikkelsen et al., Chapter 38 , this volume). Sampled units are not exclusively fine-grained. Coarser units were also drilled, and most of them were logged. Al- 
Site 942, western Amazon Fan
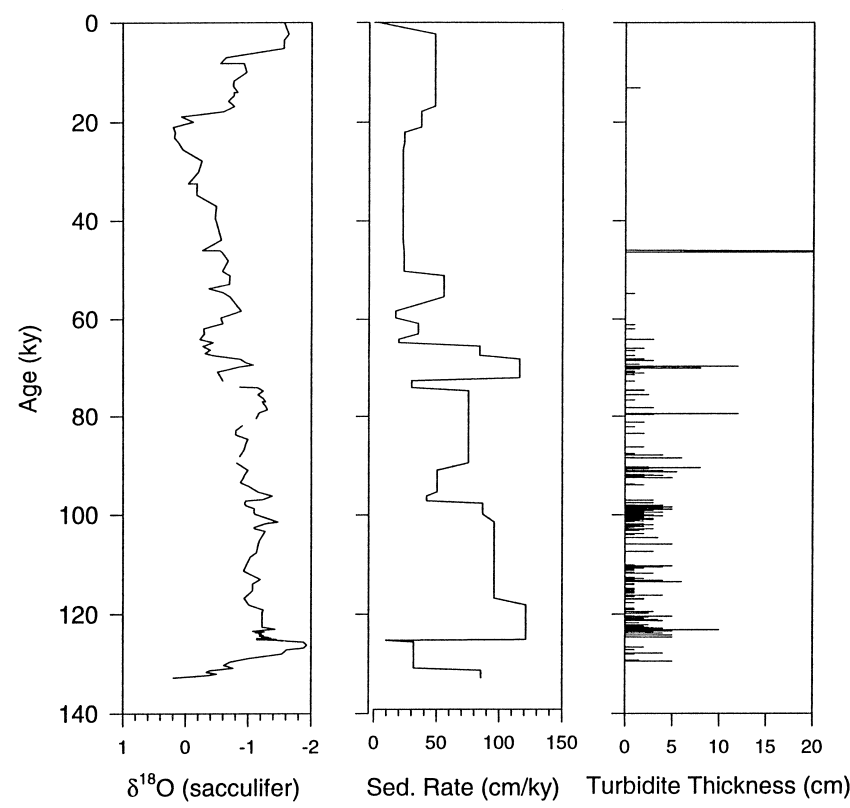

Figure 8. Age-depth plot for Hole 942A showing high rates of sedimentation due to turbidites during the Stage 5 interglacial. Sedimentation rates are higher and turbidites are frequent during minor Stage 5 sea-level falls; however, sedimentation rates are lower and turbidites are rare during the Stage 24 glacial at this site.

\section{Amazon Fan Stratigraphic Summary}

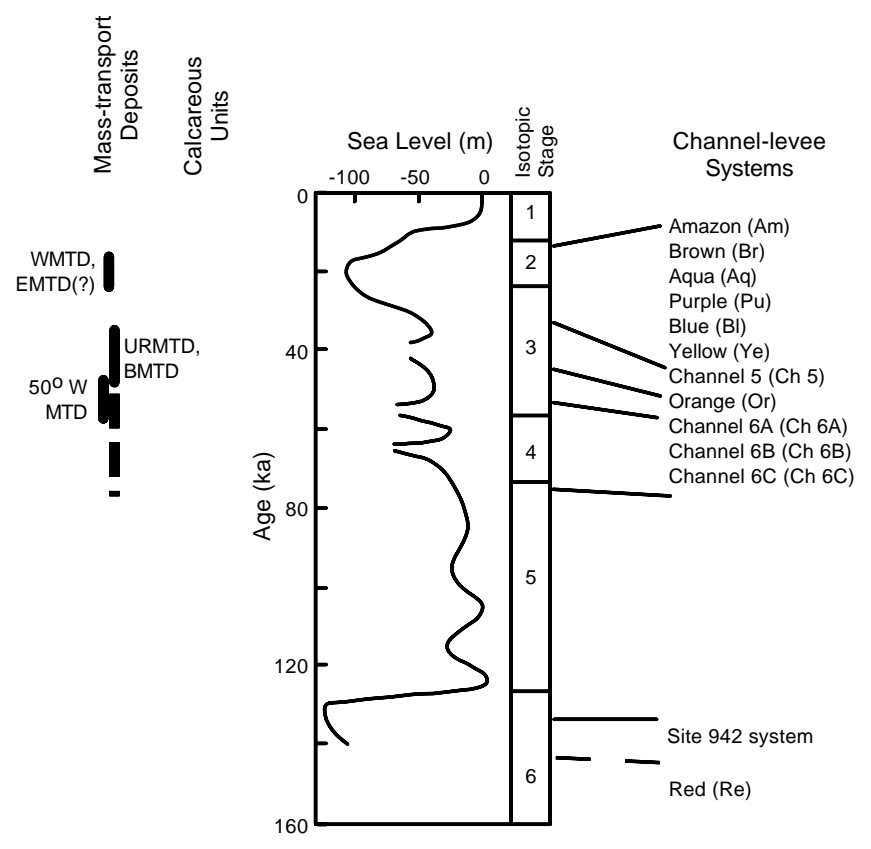

Figure 9. Sea-level curve for isotope Stages 1-6 showing the ages of the channel-levee systems (right), MTDs (left), and calcareous units. Channellevee systems are identified for all time intervals when the sea level is lower than $\sim 25$ to $30 \mathrm{~m}$ below present. Calcareous units are only present when the sea level is at its highest. MTDs, which appear to have formed when the fan was active, occurred over short intervals within the time ranges shown. though these units were poorly sampled, the logs allow for detailed facies interpretations (Pirmez et al., this volume). The relative ages of many of the coarser units can be determined through correlations through seismic records to adjacent, overlying, and underling levee sediments (Flood, Piper, Klaus, et al., 1995; Pirmez et al., this volume). The sediment section for the last $\sim 45$ k.y. (Stages 1,2 , and 3 ) is well sampled, which includes an $80-\mathrm{m}$ fall in sea level to $115 \mathrm{~m}$ below present sea level from $\sim 36$ to $26 \mathrm{ka}$ and the rise to the present sealevel high. Also sampled was a channel-levee system (Channel 6B), thought to be active from $\sim 72$ to $65 \mathrm{ka}$, and sediments were recovered from highstand deposits in Stages 1, 5, and 7 (Piper et al., Chapter 39, this volume; perhaps also in Stage 9, Mikkelsen et al., Chapter 38, this volume). The critical earliest glacial/latest interglacial time (near the Stage $4 / 5$ boundary) when the sea level fell below shelf break may not have been well sampled where the fan was active, in part because several large MTDs that were emplaced $\sim 40-80 \mathrm{ka}$. have obliterated parts of the record. However, Stage 5 can be identified on seismic records in the vicinity of the drill sites by lateral tracing of seismic reflections (Fig. 3). Control for the position of Stage 5 in the seismic records comes from Site 942 on the western flank of the fan (and tied to the main portion of the fan with a seismic profile) and Site 946 at the middle/lower fan boundary. A large or coarse influx of material during a sea-level fall has not yet been identified on seismic profiles at an interval correlative to the Stage 5/4 sea-level fall.

Analysis of the Leg 155 cores support the general observation that submarine fans are active when the source of sediment is at or near the shelf break. For the late Pleistocene with relatively short-lived highstands and wide shelves, the Amazon Fan is most active when sea level falls to or near the shelf break. When the Amazon Fan is active, the primary depositional unit in the mid fan is the channel-levee system (Figs. 5, 9), and these deposits were sampled (with some gaps in Stages 3 and 4) from $\sim 72$ to $10 \mathrm{ka}$. All of these channel-levee systems appear to have a similar structure, although the drill hole that sampled the Stage 4 channel-levee system (Channel 6B at Site 932) did not penetrate the entire deposit. The timing of individual channellevee systems appears not to be related to minor sea-level fluctuations. Shipboard descriptions and grain-size analysis (Manley et al., this volume) suggest that there is no significant variation in the overall grain size of the active levee deposits from $\sim 72 \mathrm{ka}$ to the last sealevel rise. Mineralogical variations within the levee deposits of the Upper Levee Complex have not as yet been recognized (McDaniel et al., this volume; Debrabant et al., this volume).

Site 946, near the end of the most recently active channel-levee system, may possibly have recovered some of the time interval crossing the Stage 4/5 boundary in the depth interval from $\sim 100 \mathrm{mbsf}$ (estimated at $\sim 30 \mathrm{ka}$ ) to $\sim 128$ mbsf (estimated at $\sim 100 \mathrm{ka}$; Piper et al., Chapter 39, this volume). Although thick coarse turbidite beds, some with mud clasts, are recorded in this time interval, the beds appear similar to those recovered in levee deposits and in the HARPs underlying channels in mid-fan settings (Shipboard Scientific Party, 1995e; Pirmez et al., this volume). However, we do not have sufficient data from the lower fan, nor sufficiently precise stratigraphic correlation at Site 946 , to determine the ages or precise origins of all the sand layers recovered, and the Stage 4/5 boundary at Site 946 may have been removed by the debris flow in Stage 3 .

The correlation of seismic stratigraphic units with cored sediments also suggests that channel-levee systems pass distally into thick-bedded sands with interbedded muds on the lower fan. The most recently active channel-levee system, the Amazon Channel, has followed this pattern and built across the lower fan sands (Shipboard Scientific Party, 1995e; Pirmez et al., this volume). Earlier channellevee systems, such as Aqua, also appear to have built across lower fan sands. Similarly, seismic records suggest that the lower fan sands can be correlated to the sand-rich HARP units, and detailed correlation between sites based on seismic and core data suggest that sandy units over which these channel-levee systems have built have an age 
similar to the age of those channel-levee systems. Channel-levee systems of similar structure appear to be characteristic of the entire time interval from at least $\sim 72$ to $11 \mathrm{ka}$, including a major sea-level fall ending at $\sim 20 \mathrm{ka}$ and the extended sea-level rise from $\sim 20$ to $11 \mathrm{ka}$. For example, the Blue Channel-levee System developed during a falling sea level prior to the LGM, the Brown Channel-levee System corresponds to the lowstand of sea level at the LGM, and the Amazon Channel-levee System was deposited during a rising sea level in the latest Pleistocene. All three systems show similar development, with initial HARP deposits following avulsion (Fig. 7) across which a levee system prograded.

The strong, reflective, flat-lying seismic reflections observed on the lower fan at Sites 945 and 946 are caused by thick, coarse turbidites that were deposited during periods when channel-levee systems were active on the middle fan. These sands appear to extend for cross-flow distances up to $\sim 2 \mathrm{~km}$ (between Sites 945 and 946), and thus are probably lobe-like deposits formed downfan of the end of the channel. These sandy lobes may correlate with the upfan HARPs, and their formation may be initiated by upfan channel avulsions (Pirmez et al., this volume). Following avulsion, the leveed channel prograded across the lobe-like deposits until their sediment supply was cut off by a subsequent avulsion (Pirmez et al., this volume; Hiscott et al., this volume).

These observations suggest that channelized flow processes act to concentrate coarse sediments along the channel and on the lower fan, perhaps through base-line irregularities and changes resulting from avulsions, meander cutoffs, and other natural events (Pirmez and Flood, 1995). These changes create a multistep sand transport process that can concentrate coarse-grained sediments in the middle and lower fan (seismic HARPs). These coarse deposits are genetically related to leveed channels that can form at any time when the fan is active. The existence of processes related to flow through leveed channels that concentrate significant thicknesses of sand means that a separate mechanism is not needed to emplace the sand found on the lower fan.

The sea-level rise at the end of Stage 2 is characterized across the fan by a cessation of turbidity current activity followed by the deposition of a carbonate mud when the sea level is well above the shelf and sediment is diverted to the shelf. However, for individual channels, the timing of the end of turbidity current activity varies widely because this is controlled by the age of individual channels and the changing channel pattern on the fan. An observation of reduced sediment flux and turbidity current activity at any one site is thus not sufficient to identify a sea-level rise. For the Amazon Fan, sedimentation rate decreases associated with sea-level rise are characterized by increasing $\mathrm{CaCO}_{3}$ contents and by a decrease in the relative abundance of terrestrial organics (Goñi; Hinrichs and Rüllkotter, both this volume).

Our observations on the Amazon Fan differ in two respects with the present understanding of sedimentation timing and patterns in deep-sea fan deposits. First, we have not yet identified any specific deposit formed during the initial sea-level fall at the Stage 4/5 boundary either on seismic records or in drill cores and/or logs that might correspond with a "basin floor fan" as distinct from a "slope fan." However, an unambiguous sedimentary record of the Stage 4/5 boundary was not recovered where the fan was active. Further analysis of high-resolution seismic records tied to the drill sites will be needed to determine the likely sedimentation patterns associated with this initial sea-level fall. However, we can report that none of the prominent seismic facies cored (channel-levee systems, lower-fan sands, and MTDs) appears to have been deposited during that initial sea-level fall. A deposit formed at the Stage $4 / 5$ boundary is thus likely to be relatively small. We do see some evidence for coarser sediments being transported into the deep sea during smaller Stage 5 sealevel falls at Site 942, but few coarse sediments reached that site during the larger glacial sea-level fall.
The transition from a channel-levee system on the middle fan to flat-lying sands on the lower fan observed on the Amazon Fan represents a lateral facies shift related to channel-levee processes rather than a temporal change in sediment transport processes as might be expected where a "lowstand wedge" or "slope fan" overlaps a "lowstand fan" or "basin-floor fan" (terminology of Posamentier and Vail, 1988, and Vail et al., 1991). We therefore agree with Posamentier and Allen (1993) who state, "The terms basin-floor fan and slope fan merely allude to fan-shaped bodies of sediment that occur on the basin floor or the slope, respectively, and should carry no connotation regarding any distinctive log signature, sedimentation pattern, or position within the evolution of a depositional sequence."

The second important respect in which our observations differ from general models is that coarse-grained deposits within large, muddy fans are more widespread than expected. Sands are not restricted to channels in channel-levee systems; they also are found in flat-lying deposits (seismic HARPs) that underlie channel-levee systems on the middle fan associated with channel avulsions. These HARPs appear to extend downfan to form the lower fan. These coarse deposits are not restricted to specific sea-level stages (e.g., early lowstand vs. late lowstand), but can form any time the channellevee system is active. However, if this turbidite system was active for a considerably longer time, more of the sediments stored on land would have been transported to the fan, and sediment size and mineralogy may change with time.

\section{Conclusions}

Our conclusions with regard to sea-level change can be framed in terms of answers to the following six questions that were posed prior to Leg 155 (Flood, Piper, Klaus, et al., 1995; Shipboard Scientific Party, 1995a):

1. Is there a relationship between channel-levee formation and sea-level fluctuation (i.e., do new channel-levee systems form as a result of autocyclic channel avulsion processes or are they initiated by changes in sediment supply)? Although all avulsions appear similar on seismic records, some avulsions are correlated to local increases in coarse sediment supply, whereas other avulsions show no apparent correlation with changes in sediment type. Also, changes in sediment supply associated with avulsions do not appear to be correlated across the fan as would be expected for a climatic or sea-level control. We conclude that avulsion is principally an autocyclic mechanism, related to local sediment flux and levee wall failure.

2. What relationships are there between debris flows and sea-level change? This issue is reviewed by Piper et al. (Chapter 6, this volume). Major MTDs appear to correlate with times of falling or a maximum lowstand of sea level, and gas hydrates are implicated in the triggering of failure. This interpretation is limited by our knowledge of sea-level change and the precision with which age of MTDs can be determined (Maslin and Mikkelsen, Chapter 20, this volume)

3. What seismic reflections correlate with sequence boundaries on the shelf? The LGM lowstand sequence boundary on the shelf corresponds approximately to the HARP at the base of the Brown Channel-levee System; however, this HARP unit does not appear different from HARPs found at the base of channels of different ages. The Holocene maximum flooding surface corresponds approximately to the diagenetic crust in the surficial carbonate-rich muds. This may become an important reflection after further burial.

4. What is the relationship of channel-levee systems to sequence boundaries and flooding surfaces? Flooding surfaces mark times when sediment supply to the Amazon Fan was interrupted. With falling sea level after this interruption, a new upper 
slope conduit was established, leading to the deposition of a new "levee complex." However, levee complexes on the Amazon Fan are seismically identified because they are topped by large debris-flow deposits. Levee complexes may be more difficult to distinguish where debris-flow deposits are not present. There is no simple relationship between sequence boundaries and higher order individual channel-levee systems.

5. Do the high-amplitude reflections at the base of channel-levee systems represent condensed sections during maximum flooding surfaces, so that the erosional surfaces at the bases of channel-levee systems are sequence boundaries, or are they of autocyclic origin? The HARPs are coeval with channel-levee deposits, and thus they are of autocyclic origin and cannot be correlated with sequence boundaries or flooding surfaces.

6. What is the temporal relationship of lower fan deposits (depositional lobes) to middle and upper fan deposits (channellevee systems)? They are synchronous facies equivalents.

\section{SEDIMENT LITHOLOGIES CHARACTERISTIC OF DISTINCTIVE ACOUSTIC FACIES AND SEDIMENTARY PROCESSES}

\section{Objective}

A second objective during Leg 155 was to improve our understanding of the sediment facies and growth processes of large turbidite systems. Knowledge of sediment facies and their distribution patterns in major turbidite elements (e.g., levees, channels, and lobes) can provide insights into depositional processes on the Amazon Fan that can be used to interpret processes on other modern fans and perhaps ancient turbidite deposits. Studies of modern turbidite systems, such as the Amazon Fan, provide good knowledge of the deposit morphology, based on seismic-reflection, side-scan sonar, and swath bathymetric data. However, without sediment samples (which generally have been limited to the upper $10 \mathrm{~m}$ ), only interpretive acoustic or seismic facies can be discussed (e.g., Damuth et al., 1988; Manley and Flood, 1988; and Flood et al., 1991 for the Amazon Fan). In contrast, knowledge of the sedimentary facies for ancient turbidite deposits, whether studied through outcrop mapping or with borehole data, provides only limited scope for interpreting sedimentary processes because the original shape (especially the vertical relief) of the deposit is not known as a result of compaction and, in some cases, tectonism (Normark et al., 1993). Leg 155 drilling on the Amazon Fan provided over $4000 \mathrm{~m}$ of sediment core that sampled a number of seismically imaged sedimentary environments in this large, modern, muddy fan. Analysis of these cores supplements our understanding of modern turbidite systems developed in part through Deep Sea Drilling Project (DSDP) Leg 96 on the Mississippi Fan (Bouma, Coleman, Meyer, et al., 1986). Even though the Amazon Fan is a deep-water, passive-margin deposit, to the extent that the facies for Amazon Fan might prove comparable to those from ancient turbidite deposits, the results of the drilling program can help to evaluate existing and future depositional models based on outcrop mapping (Normark et al., 1993). Only some aspects of preliminary results are reported here. Additional results of facies studies are included on the back-pocket foldout as well as in other chapters of this volume and in Flood, Piper, Klaus, et al. (1995, especially the site chapters and back-pocket foldout).

\section{Sediment Facies}

Sediment facies are described on the basis of visual core descriptions for the fan as a whole (Normark et al., this volume), on the basis of detailed visual, X-radiographic, and grain-size studies for finegrained turbidites (Piper and Deptuck, this volume), and on the basis of wireline logs supplemented by core recovery for the poorly recov- ered sandy units (Pirmez et al., this volume). Our studies have focused on sediments recovered in the middle fan region of channellevee systems, and thus other sedimentary environments, such as the lower fan, are less well represented. Normark et al. (this volume) summarize 15 major sediment facies on the basis of Leg 155 cores based on bed-by-bed descriptions of the recovered sediments and integrated with seismic profiles (Fig.10). Of particular interest is the distribution of the sand facies. The coarsest grained facies recovered (Facies 1: disorganized gravel and sandy gravel) and two other sand facies (Facies 2: disorganized sand beds [structureless and chaotic] and Facies 3: organized sand beds [graded and cross-stratified]) are found in the HARP layers that underlie the middle-fan channels and continue downslope to the lower fan (Facies 1-3) and in channels (Facies 3). Pirmez et al. (this volume) use wireline logs (especially FMS) to characterize the sandy facies, and note that sand bodies 5 to $25 \mathrm{~m}$ thick (formed from beds 0.1 to $4 \mathrm{~m}$ thick) are present in the HARP units beneath mid-fan channels (Fig. 11), and that sand bodies up to $50 \mathrm{~m}$ thick (with individual beds often exceeding $3 \mathrm{~m}$ thick and containing mud clasts) are present on the lower fan. The mud clasts in this and other coarse facies are eroded levee deposits. The distribution of coarse-grained facies is consistent with sand bodies underlying the levee being formed following an avulsion (Pirmez et al., this volume; Normark et al., this volume).

\section{Sedimentary Processes}

Sedimentary process studies to date include the nature of turbidity current flow in the active fan channel (Hiscott et al., this volume), the frequency of turbidite activity as determined from fine-grained turbidites (Piper and Deptuk, this volume), and the character and timing of MTDs (Piper et al., Chapter 6, this volume). Hiscott et al. (this volume) measured grain-size characteristics of the coarsest turbidite layers on the channel (the overbank deposits) to estimate the characteristics of the turbidity currents flowing through the channel. Pirmez (1994) estimated, based on meander curvature, flow density, flow depth, and channel gradient and that channelized turbidity currents flowed at $\sim 0.5$ to $2.0 \mathrm{~m} / \mathrm{s}$ on the middle fan, decreasing to 0.5 to 1.5 $\mathrm{m} / \mathrm{s}$ on the lower fan. Grain-size characteristics in overbank deposits were consistent with these flow velocities and suggest that a single type of mixed-load turbidity current could have transported very coarse sand as bedload along the channel talweg and contributed to levee growth by spilling a suspension of mainly silt and mud from the flow top (Fig. 12). The loss of material from the flow through overbank spilling is compensated for by the thirty-fold decrease in channel cross-sectional area downfan, resulting in a turbidity current flow that evolves downfan. Analysis of the frequency of fine-grained turbidites on the levees suggests that turbidity current flows traverse the active channel about once every 3 to 8 yr (Piper and Deptuk, this volume). In contrast, the Stage 5 turbidite record recovered at Site 942 suggests that turbidity currents occurred about once every $10-50 \mathrm{yr}$ when that system was active (Fig. 8).

Mass-flow deposits form a significant component of the Amazon Fan in the region studied. Most prominent are several thick deposits studied by core analysis and with wireline logs (summarized by Piper et al., Chapter 6, this volume). Most deposits consist of large deformed blocks of clayey sediment with dimensions of meters to decimeters. Some of the weaker, smaller blocks are highly deformed, and there is usually little matrix recognized between blocks. Only some thin, matrix-rich deposits with small clasts near the top of some units are true debris flows. The MTDs appear to have been initiated in slope and upper fan levee sediment (see also Vilela and Maslin, this volume), and they show a repetitive character vertically, suggesting formation by retrogressive failure from a headwall scarp. Some sediment at the base of the flows resembles deep-water levees, and deformed carbonate-rich units are sometimes at the base of the flows suggesting preferential sliding on carbonate units. MTDs were partly 


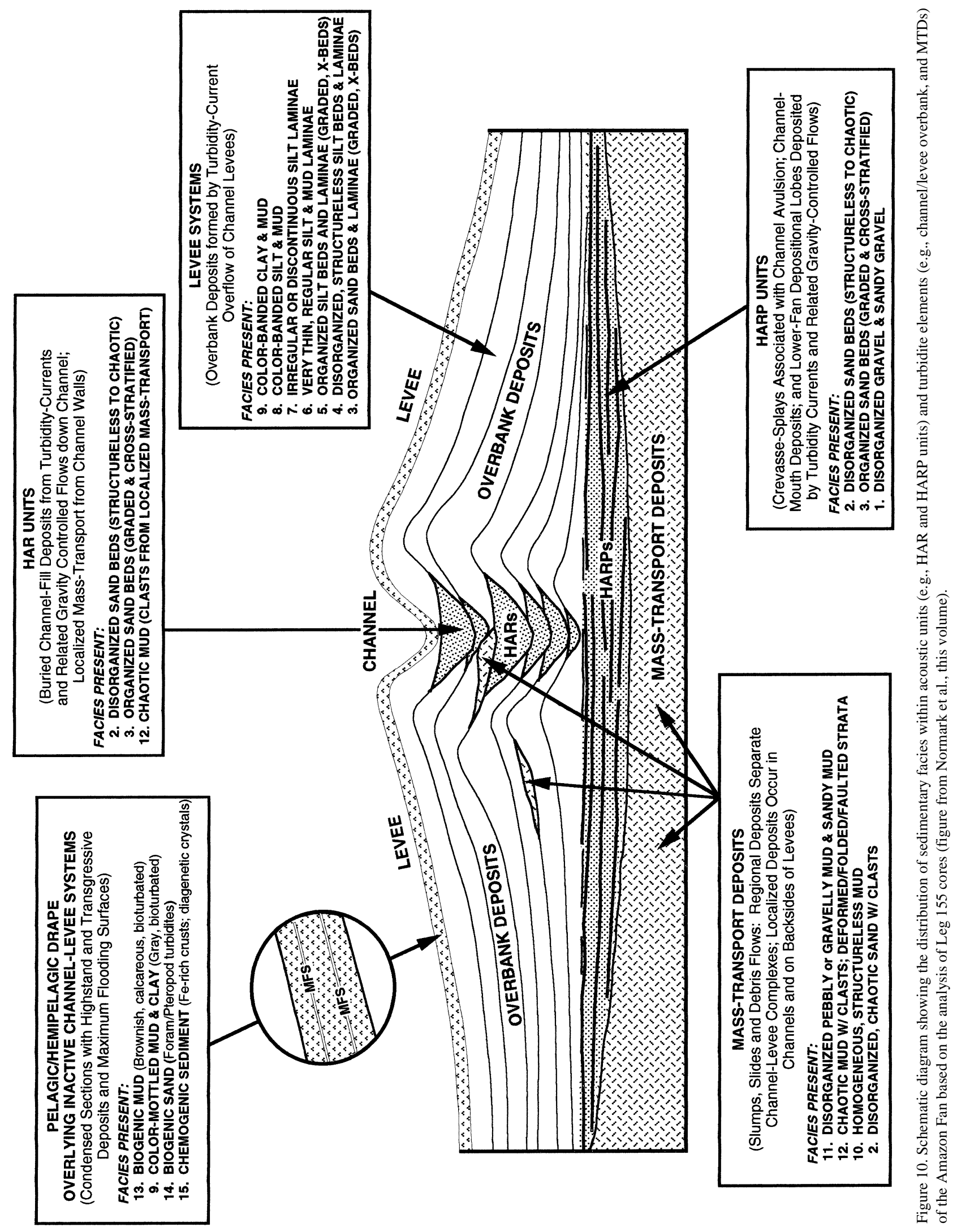




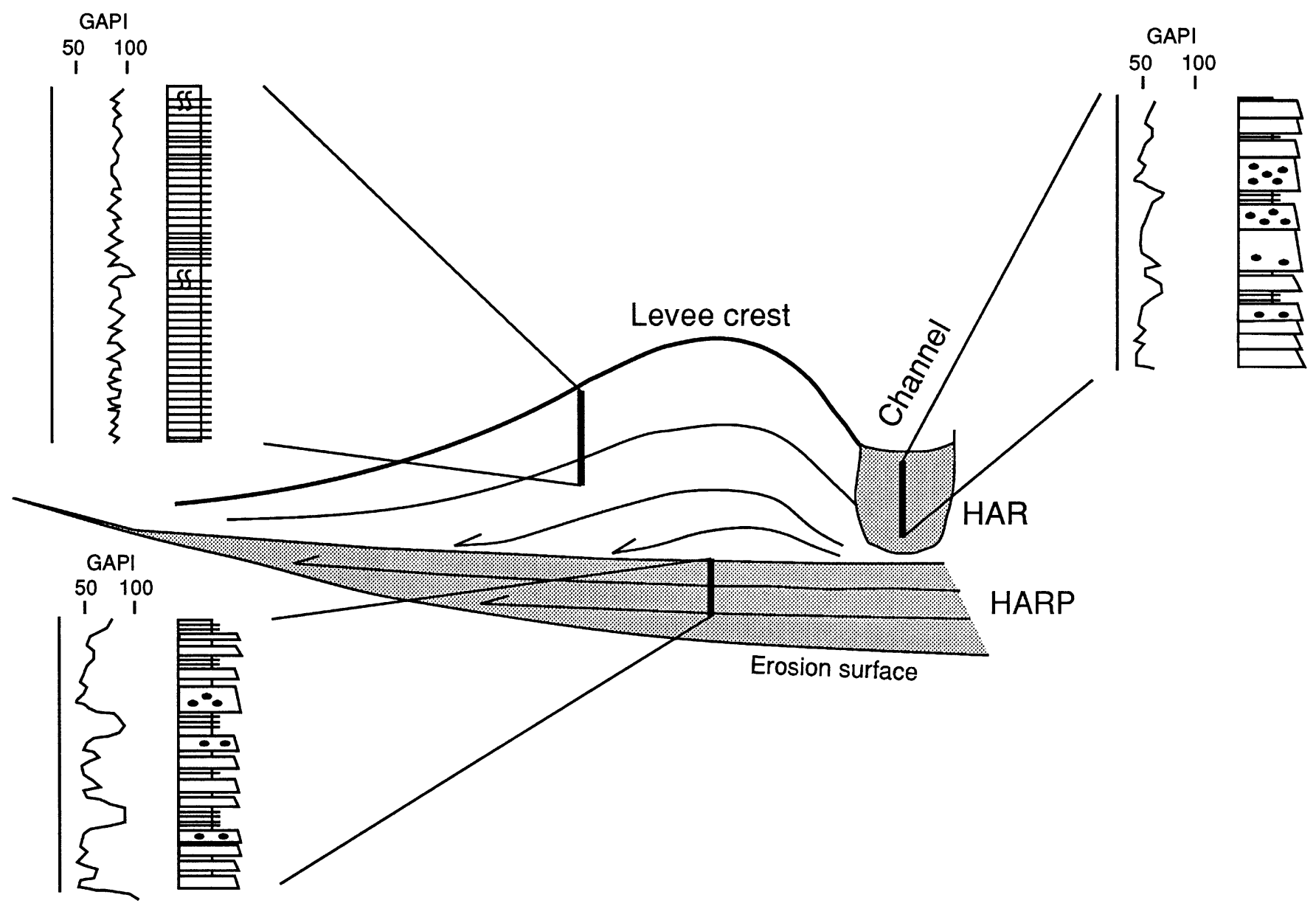

Figure 11. Summary of the geometry, stratigraphy, lithofacies, and gamma-ray signature of components of Amazon Fan channel-levee systems based on seismic profiles, cores, and wireline logs (figure from Pirmez et al., this volume).

confined by pre-existing channel-levee topography on the fan, but in places, high-relief levee deposits were eroded by the mass-transport flow and incorporated in the basal part of the deposit. Analysis of available data suggests that these MTDs formed when the fan was active (low sea level) in sediments that were underconsolidated because of rapid deposition, shallow gas, and/or gas hydrates, or decomposition of iron monosulfide. Local steepening and weakening by diapiric intrusion may also have facilitated failure. A negative carbon isotope event in planktonic foraminifers may correlate with the most recent MTD, possibly indicating a large gas release from the sediments (Maslin et al.; Maslin and Mikkelsen, both this volume).

\section{Conclusions}

Preliminary analysis of over $4000 \mathrm{~m}$ of core recovered from over $5000 \mathrm{~m}$ drilled at 17 sites on the Amazon Fan has resulted in the description of 15 overall sediment facies. Facies patterns from the midand lower fan region, as well as analysis of log patterns for poorlyrecovered sandy sediments, are consistent with the existence of prominent sand units up to $25 \mathrm{~m}$ thick (and contained in the seismically defined HARP units) that underlie channel-levee systems on the middle fan and that extend downfan to form a significant part of the lower fan. Some of the sand units contain deformed mud clasts that were ripped from channel walls. The sandy HARP units form shortly after the base level of the turbidity current channel is lowered at the downfan end by the failure of the channel wall. This base-level fall is accompanied by downcutting in the turbidity current channel that results in the remobilization of channel-floor sands, and the remobilized sands deposit as unconfined sheet flows downfan of the avulsion point. With time, the channel gradient is re-established, and the leveed channel progrades downfan. Sandy deposits continue to accumulate at the end of the channel, forming a lobe-like deposit that shifts downfan as the channel progrades. These channel-mouth deposits appear to form a large portion of the seismically identified lower fan.

In other settings, the base-level drop that apparently results in HARP formation could be due to processes other than channel-wall failure, including diapirism, salt tectonics, and tectonic movements. Indeed, Pirmez et al. (this volume) and Hiscott et al. (in press) note that the sheet-like sandy units described from the Amazon Fan appear to be indistinguishable in facies and sand content from many described mud/sand-rich successions thought to be more typical of smaller, sand-rich fans, including some hydrocarbon-producing turbidite deposits. On the Amazon Fan, avulsions occur at 3- to 10-k.y. intervals, suggesting that these sand layers are rapidly formed. Thus sand deposits in large, muddy turbidite systems can form rapidly (in less than a few thousand years), and that sand-layer deposition may occur any time a leveed channel is active. The role of leveed channels in supplying sand to interchannel depressions following base-level changes needs to be more carefully considered. 


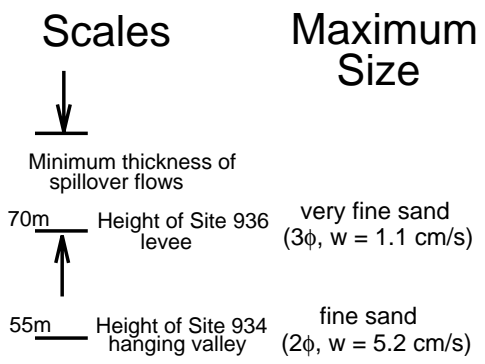

Figure 12. Theoretical velocity and concentration profiles of turbidity currents (from Stacey and Bowen, 1988; right) and maximum size expected at different levels in the flow (left) for predicted Amazon Fan turbidity current flows (figure from

0 Channel floor very coarse sand $(-1 \phi, w=26 \mathrm{~cm} / \mathrm{s})$

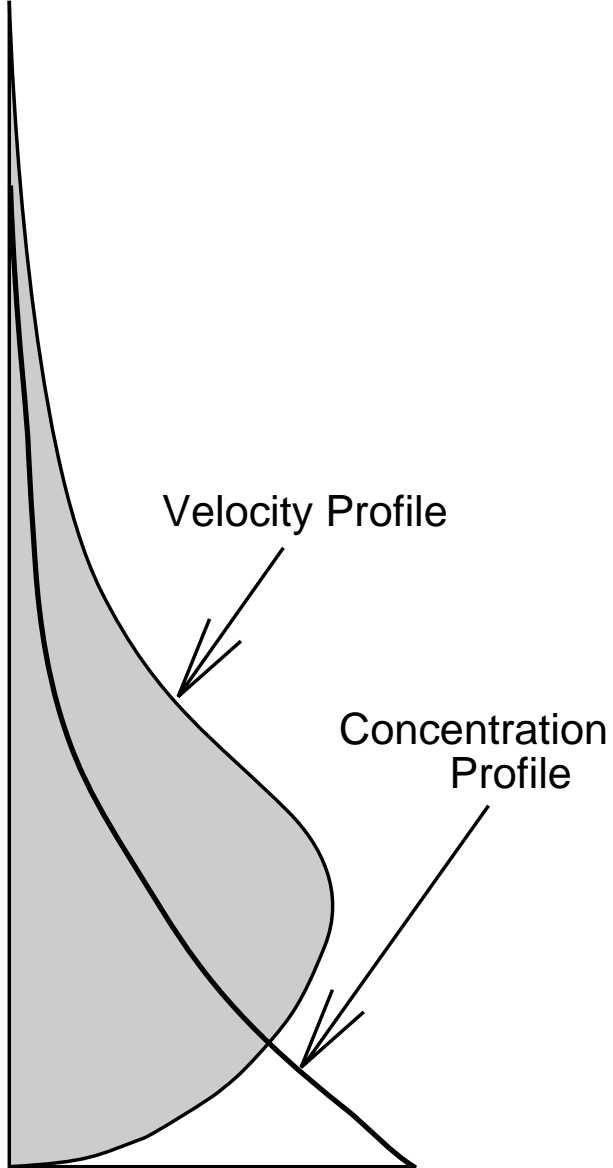

North Brazil Coastal Current (NBCC) is the only known cross-equatorial heat transport in the global circulation pattern (Metcalf and Stalcup, 1967; Richardson and Walsh, 1986). From December to June, the NBCC may extend into the Guiana Current and link with the Caribbean Current when wind stress variation causes increased transport in the NBCC (Picaut et al., 1985; Philander and Pacanowski, 1986). However, the NBCC turns eastward (retroflects) into the eastward-flowing North Equatorial Countercurrent (NECC) between July and November. The amount of cross-equator heat transport depends in part on the duration and timing of the strong northward NBCC flow, and cross-equator heat and salt transport may be reduced if the duration of the NBCC retroflection increases. If this were the case in the past, then circulation patterns of the glacial western tropical Atlantic could at times have been very different from the modern-day circulation regime.

Lenses of low-salinity surface water resulting from dilution of the Amazon plume occasionally become detached and can move seaward, perhaps also as a result of weakening trade winds, NECC eddies, or variations in Amazon River discharge (Nittrouer and DeMaster, 1986; Nittrouer et al., 1995). During lowstands of sea level, the river would have discharged directly into relatively deep water, and mixing of the river plume into the coastal water might have occurred more slowly than at present, allowing more extensive freshwater lenses to form. Variations in the strength of the NBCC may result in locally fresher or saltier surface waters, and evidence for this may be present in the planktonic oxygen isotopic record. Variations in seafloor and latest glacial maximum oxygen isotopes both show the influence of light Amazon water (Fig. 13).

Some insights into present-day circulation patterns can be gained from the study of diatoms in Amazon Fan sediments, although diatoms are preserved only in low sedimentation rate sediments of the late glacial or early interglacial periods ( $<12 \mathrm{ka}$; Mikkelsen, this vol- 
A

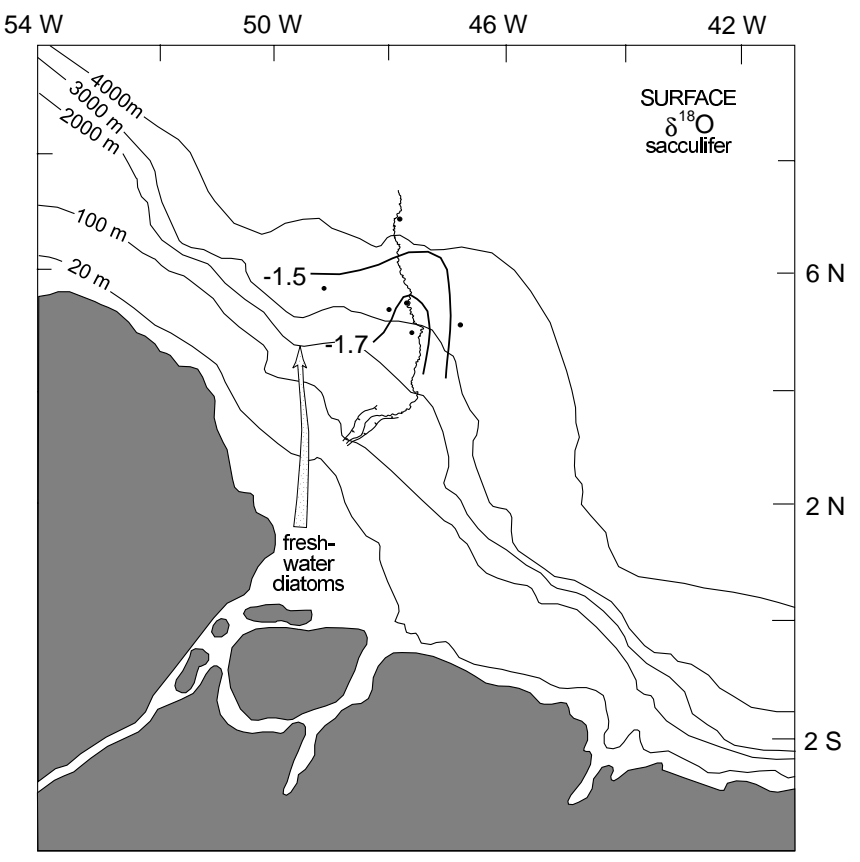

B

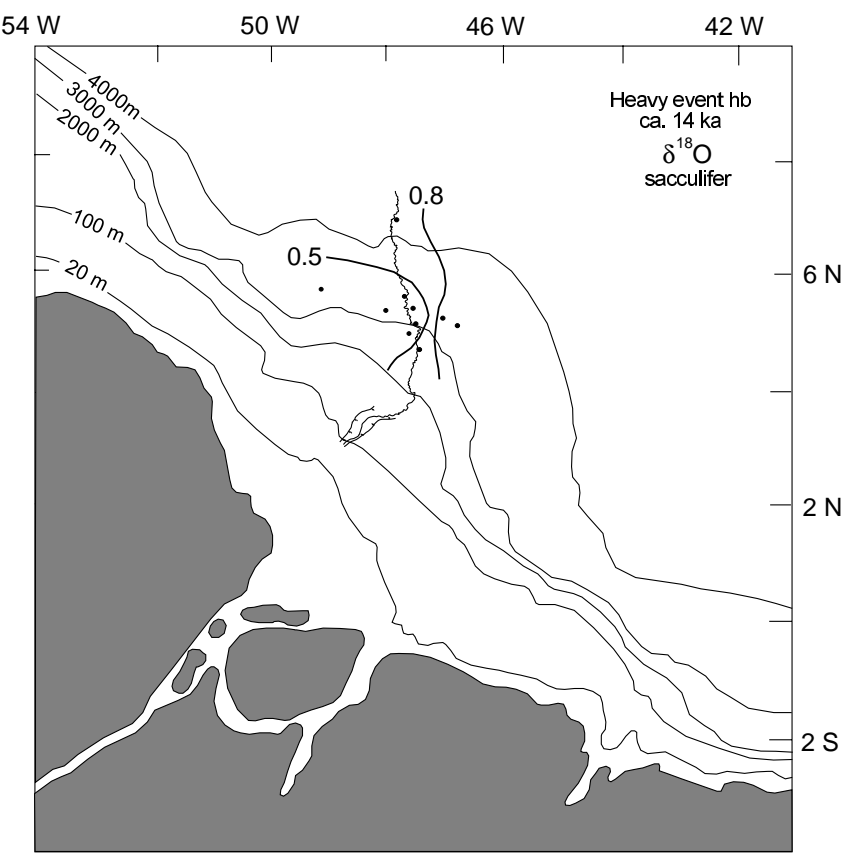

Figure 13. (A) Surface and (B) $\sim 14 \mathrm{ka}$ isolines of $\delta^{18} \mathrm{O}$ for G. sacculifer on the Amazon Fan, showing the steep environmental gradients. Dots indicate sites with data (see Showers et al.; Piper et al., Chapter 39, both this volume).

ume). Analysis of Holocene sediments show that $10 \%-30 \%$ of the diatoms are freshwater species except at Site 942 , where $~ 75 \%$ of the diatoms are of freshwater origin. The higher percentage at Site 942 seems to be caused by northward or offshore transport of Amazon River water, demonstrating that there are regional influences of surface circulation patterns recorded in Amazon Fan sediments. Unfortunately, due to dissolution, diatoms cannot be used to study surface circulation changes in the glacial period.

Sufficient planktonic foraminifers are preserved in fan sediments to allow for systematic isotopic analysis. The present isotopic data set is summarized by Showers et al. (this volume), but see also Maslin et al. (this volume) and Schneider et al. (this volume) for more detailed depositional models at specific sites. The consistency of isotopic data between closely spaced sites (Piper et al., Chapter 39, this volume) and between closely spaced samples at individual sites confirms that the features on the isotopic data in general are real and not artifacts of variably reworked foraminifers. Either the analyzed foraminifers are in situ pelagic deposits interbedded with frequent thin turbidites, or, if reworked, they derived from young surface pelagic deposition. The rapid rates of sedimentation on the proximal Amazon Fan and the tendency for channels and levees to aggrade mean that older foraminifers are rapidly buried.

This analysis has resulted in an oxygen isotope data set that can be correlated to the global isotopic record and that can be used to develop a depositional history of fan sediments deposited during the last glacial period (Stages 2-4), to identify sediments deposited during sea-level highstands (Stages 5, 7, and perhaps 9), and to aid in identifying the source of sediments that have created the several large MTDs (see also Piper et al., Chapter 6, this volume).

To date, Leg 155 studies of ocean paleoclimate have focused on the planktonic isotopic record at two sites where expanded records are present on distal levees (Fig. 14; Sites 932 and 942). Useful initial information has also come from Sites 933 and 938 where the sedimentary record may be more complex. Quite rapid lateral variations in isotopic composition of planktonic foraminifers on the fan (Fig. 13) reflect the complex oceanographic setting but hinder correlation between sites. Comparing results at different sites is further complicated by the lateral and downcore variability in sedimentation rates and the use of different species and different size ranges, choices necessitated by the generally low abundances. Results to date are also based on initial sampling at 50- to $150-\mathrm{cm}$ intervals, giving a temporal resolution of 100 to $400 \mathrm{yr}$ per sample. Despite these complications, a consistent ocean isotopic record appears to be developing. Reconciling different interpretations of these records will require more detailed sampling, better age control, and a detailed understanding of the sedimentary sequences that contain the records.

Maslin et al. and Schneider et al. (both this volume) report the existence of heavy oxygen isotopic events. At Site 932, records of different planktonic species show heavy oxygen isotopic events of $0.5 \%$ o- $1 \%$ o (Maslin et al., this volume). To enhance this record, Maslin et al. (this volume) created a composite curve based on analyses of several planktonic species, which suggests that there have been six pronounced heavy oxygen isotope events in the last $50 \mathrm{k} . \mathrm{y}$. , and that these events appear to correspond to Heinrich Events H1- H5 identified in the North Atlantic Ocean. Maslin et al. (this volume) suggest that these heavy events may be caused by extended NBCC retroflection and a resulting increase in surface-water salinity and a decrease in heat and salt flux to the North Atlantic. At Site 938, a pronounced heavy oxygen isotopic event $(0.5 \%$ ) is identified at Stage 3.0, 24 ka (Schneider et al.; Showers et al., both this volume). Schneider et al. (this volume) correlate this event to a sea-surface temperature minimum in the Benguela Current being advected north from the Southern Ocean, but the timing also may be consistent with Heinrich Event H2. Neither Maslin et al. (this volume) nor Schneider et al. (this volume) shows negative isotopic events similar to those described by Showers and Bevis (1988) based on piston cores from the Amazon Fan, but the sampling interval used to date is much coarser than that used by Showers and Bevis (1988).

Maslin et al. (this volume) and Schneider et al. (this volume) both also report the existence of light-carbon isotopic events. At Sites 932 and 933, Maslin et al. (this volume) report negative deviations of $0.5 \%$ o-2\%o at $\sim 12-15 \mathrm{ka}$ (Sites 932 and 933 ) and a grouping of negative events between $\sim 26 \mathrm{ka}$ and $32 \mathrm{ka}$ (Site 932). Light-carbon isotopic events are recorded at $\sim 24 \mathrm{ka}, 55-70 \mathrm{ka}$, and $80 \mathrm{ka}$ at Site 942 (10, 18-22, and 33 mbsf; Schneider et al., this volume) and during the last deglaciation and at $\sim 24 \mathrm{ka}$ at Site 938 (5 and 138 mbsf; Schneider et al., this volume). Maslin et al. (this volume) suggest that this lightcarbon event may be related to either more extensive distribution of 

records from Sites 932 and 942, $250 \mathrm{~km}$ apart, showing the influence of surface-water variation on the fan. LM = Lake Mungo paleomagnetic Excursion. Paleomagnetic model from Cisowski and Hall (this volume). $h a-h g$ are heavy isotopic peaks recognized by Piper et al. (Chapter 39, this volume).
Figure 14. Comparison of planktonic isotopic
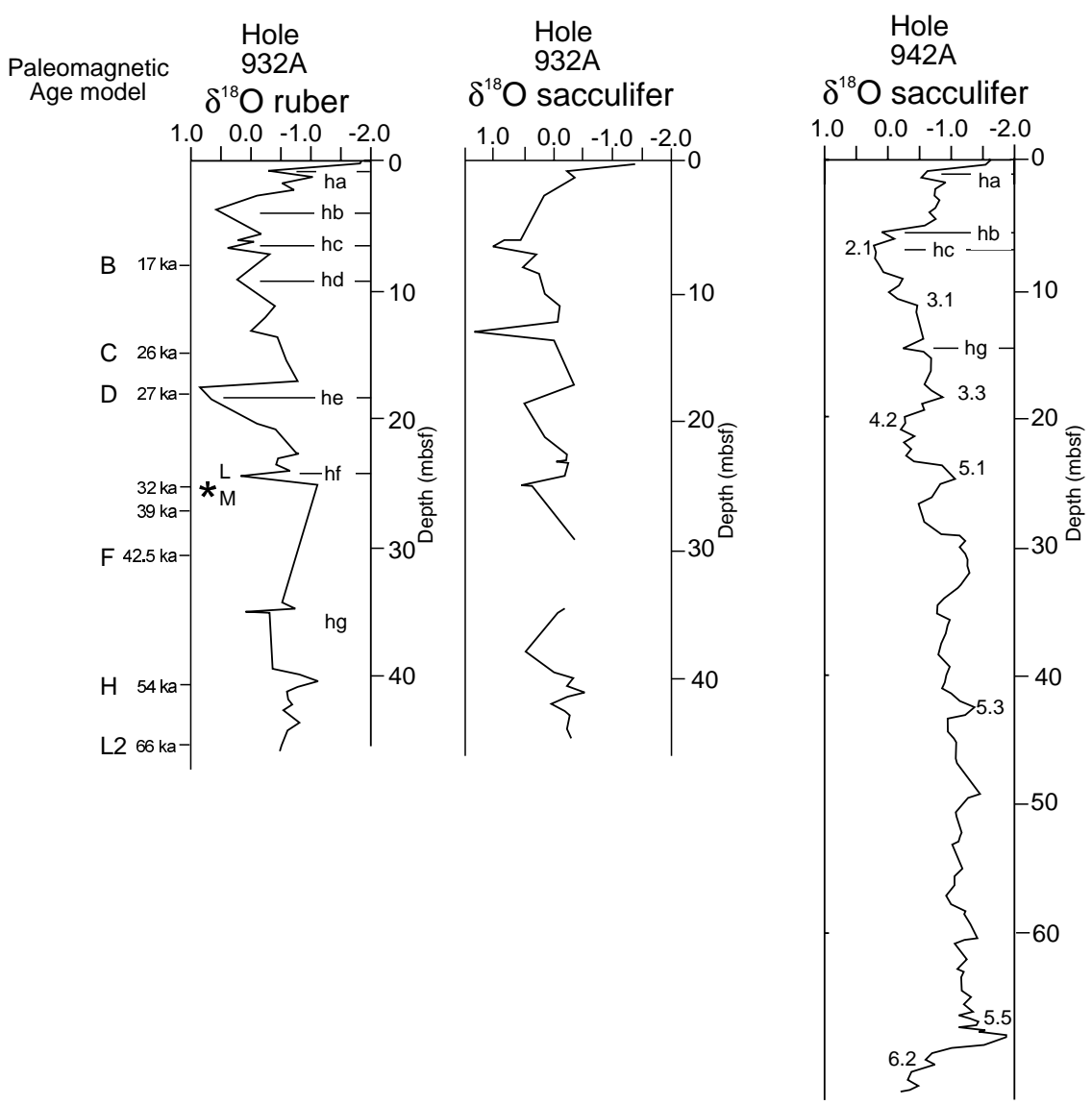

Amazon-derived organics in the surface-water column, or to light carbon introduced to the water column through slump-related disassociation of gas hydrates (see discussion in Maslin et al., this volume). The ages of light-carbon isotope events are not particularly consistent with the age range of the MTDs (Piper et al., Chapter 6, this volume). However, Schneider et al. (this volume) prefer to associate the negative events observed on the fan to changes in large-scale surface circulation, including the Benguela Current, the South Equatorial Current, and the NBCC, and the advection of events originating at high latitudes in the southern ocean to the northern hemisphere. This view appears to be supported by the existence of light-carbon events at 13-14 ka near the Antarctic polar front and off Northern Namibia (see discussion in Schneider et al., this volume).

\section{The Land Record}

Studies of land fauna and Pleistocene geology within the Amazon drainage basin have suggested that during glacial intervals, the vast tropical rain forests shrank and semiarid savannahs probably prevailed over much of the eastern Amazon (Colinvaux, 1989). However, the continental record of these changes remains sparse and incomplete (Absy et al., 1991; Liu and Colinvaux, 1988). The pollen record in marine sediments from piston cores off northern Brazil suggests that savannah was an important type of vegetation in the Amazon Basin during the LGM and that mangroves expanded along the coast in response to rising sea level during the transition from the last glacial to the present full interglacial (Holocene; Caratini and Tissot, 1976; Caratini et al., 1978).

During sea-level lowstands, river-derived materials are delivered directly to the Amazon Fan and are deposited in channel levees as well as dispersed across the fan. By reading the record of river-derived materials, we expected to gain new evidence about glacial climate within the Amazon drainage basin. This information can come from the record of plants contained in pollen and spores, from the character of the organic compounds preserved in the sediments, and from the nature of the lithogenic material itself.

\section{Pollen, Spores, and Phytoliths}

Pollen is much more abundant at lowstands of sea level than in Holocene and interglacial sediments. Preliminary studies of the pollen and spore records have been undertaken by Haberle (this volume) and Hoorn (this volume) and of the phytolith record by Piperno (this volume). These studies present a consistent view of the changing nature of glacial flora in the Amazon River drainage basin. Haberle (this volume) compared the pollen record observed on the Amazon Fan with samples taken along the modern Amazon River and concluded that there was an increase in cold-adapted arboreal taxa throughout the last glacial, peaking between 21 and $17 \mathrm{ka}$ in response to a colder, possibly dryer climate (Fig. 15). The pollen record suggests that there were only moderate increases in savannah during the last glacial period. Haberle (this volume) also suggests that the pollen assemblage is consistent with less forest flooding, perhaps due to a more deeply cut Amazon River channel when sea level was low. Hoorn (this volume) noted that palynomorphs decrease along channel from Sites 940 and 944 to 946 . She also noted that the last glacial is consistently represented by an increase of fern, fern allies, and fungal spores. However, this may be due to enhanced erosion on land during the glacial sea-level low, and the resultant proliferation of ferns over barren ground. Piperno (this volume) suggests from a study of phytoliths 


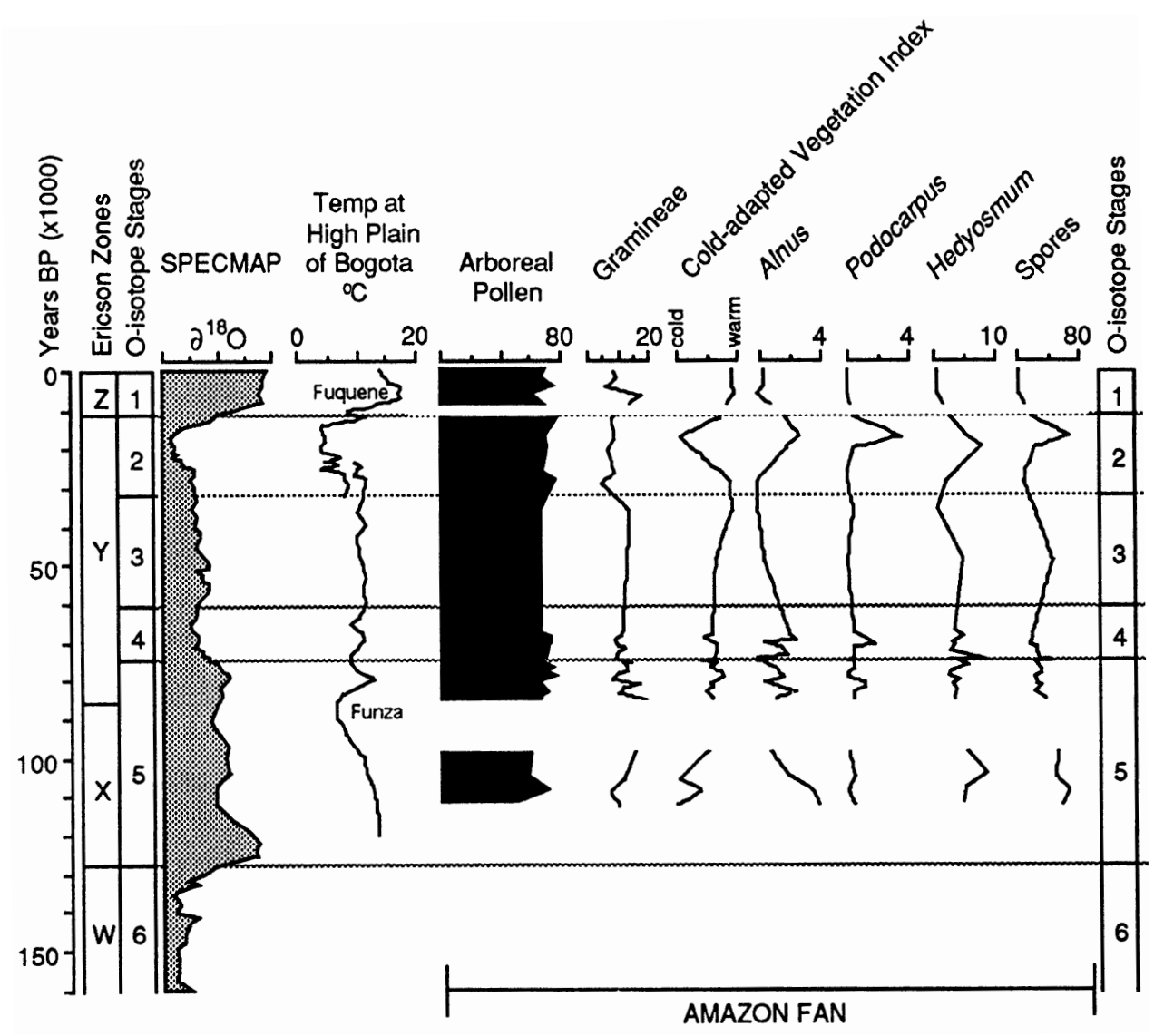

Figure 15. Correlation of the Ericson Zones, SPECMAP oxygen isotope record, and pollen records (including the Cold-Adapted Vegetation Index) assembled from Holes 932A and 946A, and climatic records at Fuquene and Funza (figure from Haberle, this volume; see Haberle, this volume, for discussion). These records suggest a colder, dryer Stage 2 in the Amazon drainage area.

and microscopic charcoal that the glacial maximum appears to have been significantly dryer than the postglacial era with frequent grassland fires. These data also reveal the highest percentages of $\mathrm{C} 4$ grasses (the grasses likely to expand at the expense of forests and C3 grasses during dryer climatic intervals) and burnt grasses during the LGM.

Overall these data suggest that the LGM was a cooler time than the present interglacial, and that cold-adapted Andean forests expanded to lower altitudes. The last glacial time was also somewhat dryer, and $\mathrm{C} 4$ grasses and fires increased. However, these workers suggest that the pollen and phytolith data do not support the existence of large-scale vegetation changes in the Amazon River drainage ba$\sin$ and the formation of rain forest refugia. Haberle (this volume) suggests that the Amazon Fan data are consistent with LGM simulations that suggest a reduction in precipitation of $20 \%-25 \%$, which would result in savannah cover over $32 \%$ of the drainage basin. Model predictions based on a $40 \%$ reduction in precipitation with rain forest refugia and $80 \%$ savannah cover are less consistent with the fan data. Piperno (this volume) notes that the accumulated evidence suggest that Pleistocene climate in the Amazon River drainage basin was dynamic, varying between cool and relatively moist to very cool and dry, and that the basin may have held the largest, continuous block of forest near the equator, but that the trees that made up that forest were not all of the same trees found in the modern lowland forest. Piperno (this volume) also notes that many highly distinctive and unknown types of pollen and phytoliths were retrieved from the Amazon Fan, strengthening the case for more complete modern reference collections.

\section{Terrestrial Organic Matter}

The organic matter preserved in Amazon Fan levee deposits (discussed in more detail in the next section) is almost entirely derived from terrestrial sources. The $\delta^{13} \mathrm{C}$ of total organic carbon (TOC) in fan levee deposits is quite constant at $\sim 27.5 \%$ o throughout the last glacial period (Goñi; Schneider et al., both this volume), consistent with terrestrial organic matter dominated by $\mathrm{C} 3$ plants. If extensive regions of $\mathrm{C} 4$ grasses had been developed during the LGM, then heavier $\delta^{13} \mathrm{C}$ of TOC would be expected, since $\mathrm{C} 4$ grasses have values averaging 13\%o. This effect should be most pronounced at Site 940 where levee deposition was occurring during the LGM, but the $\delta^{13} \mathrm{C}$ record at Site 940 is quite constant at $\sim 27.5 \%$ o, except for a bioturbated interval at $\sim 70 \mathrm{mbsf}$ where there may be some inmixing of marine carbon. Alternatively, the $\delta^{13} \mathrm{C}$ of TOC may not be a very sensitive indicator to changing abundances of $\mathrm{C} 4$ grasses in the Amazon River basin given the large amount of $\mathrm{C} 4$ carbon transported by the river (Goñi, this volume).

\section{Sediment Geochemistry and Mineralogy}

Sediment geochemistry and mineralogy provide important evidence on the source (provenance) of sediments and their geochemical history. This information can be used to characterize source areas (e.g., old shield rocks vs. younger orogens based on mineral composition, $\mathrm{Nd}$ isotopic composition, and mean sediment source ages from whole-rock dating) and the intensity of weathering or diagenesis (e.g., major element chemistry, trace and rare-earth element patterns, 
clay mineralogy). Through such analysis we may be able to determine temporal changes in source rock areas (e.g., shield vs. Andes) as well as variations in the intensity of weathering on the craton. The manner in which these indicators co-vary should help us to understand the relative contributions of sea-level change and land climate on sediment supply and composition.

Gibbs (1967) estimated that suspended sediment and dissolved solids reaching the mouth of the modern Amazon River is more than $80 \%$ derived from the Andes, although the Andes comprise only $15 \%$ of the present-day Amazon drainage basin. The modern river transports sand with a high proportion of rock fragments and few feldspars (Franzinelli and Potter, 1980); however, characteristics of the river load are poorly known for glacial times (Milliman et al., 1975). Data available prior to Leg 155 suggested that the bulk chemistry of the uppermost Pleistocene fan sediment $(\sim 11 \mathrm{ka})$ is broadly similar to that observed today (Kronberg et al., 1986; Nesbitt et al., 1990).

Information on sediment provenance comes from studies of $\mathrm{Nd}$ and $\mathrm{Pb}$ isotopes of Amazon Fan muds (McDaniel et al., this volume) and visual and electron microprobe studies of detrital grains (Nanayama, this volume). McDaniel et al. (this volume) show that the dominant source of $\mathrm{Nd}$ and $\mathrm{Pb}$ is the Andes, although there is some evidence for a cratonic component. Although there is some evidence for change in source area in different glacial periods, additional studies will be needed to further evaluate these changes. Detrital grains can be traced to source areas in the Precambrian shield areas, to arcvolcanic rocks of the Andes, and to granitoids in the Andes (Nanayama, this volume).

McDaniel et al. (this volume) also discuss bulk sediment chemistry of Amazon Fan muds as an indicator of the intensity of continental weathering. These analyses suggest that glacial Amazon Fan sediments show a moderate degree of weathering, and in particular that the bulk sediments do not appear to have been significantly affected by the harsh weathering conditions that characterize the modern Amazon Basin.

Clay minerals show temporal variations that relate in part to erosion on the continent and in part to weathering on the continent (Debrabant et al., this volume). During glacial times of lowered sea level, smectite and kaolinite were contributed through soil erosion in the lower and middle portions of the Amazon Basin, whereas illite, chlorite, and other clay-sized minerals were supplied by erosion in the Andes. The more recent sediments are enriched in smectite or kaolinite. This change in clay mineral assemblage in the Holocene appears to be caused by increased weathering on the continent.

\section{Conclusions}

Leg 155 has contributed to characterizing the LGM climate of the Amazon Basin in order to discriminate between various paleoclimatic simulations. Detrital palynomorphs and phytoliths indicate that the basin was cooler but experienced only a modest increase in savannah cover. The very size of the Amazon Basin makes climatic interpretation of the detrital sediments, dominantly from the Andes, more difficult. The next stage of investigations of Leg 155 material should be detailed studies of cyclicity in discharge of sediments and palynomorphs, now that site-to-site correlations and a working age model are available.

\section{NATURE, ORIGIN, AND EARLY DIAGENESIS OF ORGANIC CARBON}

\section{Objective}

The fourth objective posed for Leg 155 was to determine the nature, origin, and early diagenesis of organic carbon present in different fan units. Organic compounds that accumulate in the ocean con- tain important records of land and ocean climate, but to interpret them one needs to understand how sediments are delivered to the site of deposition and what transformations may occur as the sediments are buried (Aller et al., 1996). Understanding these relationships on the continental margin, and especially on fans, is important because sediment accumulation rates are high and variable during times of lowered sea level, and thus the amount and quality of organic matter preserved may be different than observed today (Keil et al., 1994). Initial studies conducted on Leg 155 sediments helped determine the nature and variability of organic matter and its initial diagenesis in different fan units. These studies are of particular interest on the Amazon Fan because organic matter of the Amazon River and modern shelf deposits has been extensively studied (e.g., Ertel et al., 1986; Hedges et al, 1986; Showers and Angle, 1986; Aller et al., 1996). Complementary studies of the organic record of fan sediments can provide information about the processes of organic matter transport and deposition in the glacial ocean as well as the character of the Amazon drainage basin during glacial intervals.

\section{Delivery of Terrestrial Organics to Fan Sediments}

Much of the organic matter transported by the modern Amazon River consists of organic compounds mostly adsorbed onto sediment particles (Keil et al., 1994; Mayer, 1994; Keil et al., this volume). The binding of this organic matter to sediment particles, and transformations of organic matter as sediments pass from the river to the ocean, can be understood in terms of the ratio between organic carbon content and mineral surface area (OC:SA; Keil et al., 1994; Mayer, 1994). Where more labile organic matter is attached to sediment particles, OC:SA is relatively higher, whereas when the organic matter is somewhat older and has been degraded, OC:SA is lower. For the Amazon River, OC:SA ranges from $\sim 0.42$ to $0.95 \mathrm{mg} / \mathrm{cm}^{-2}$ (average 0.67 ), although for modern delta sediments, OC:SA ranges from $\sim 0.18$ to $0.40 \mathrm{mg} / \mathrm{cm}^{-2}$ (average 0.30 ; Fig. 16 ). The lower OC:SA ratio for shelf sediments is interpreted to mean that organic matter initially on the particles has been remineralized during cycles of repeated deposition, erosion, and transport (see discussion in Keil et al., this volume). In part because of this remineralization, only about onefourth to one-third of the organic matter delivered to the Amazon Delta during the modern highstand of sea level is buried. Hedges and Keil (1995) suggest that sediments deposited on the fan during times of lowered sea level would have higher OC:SA ratios because sediments would bypass the shelf and thus not be affected by the remineralization that occurs there.

Variations in OC:SA were studied at Sites 932 and 942 (Keil et al., this volume). In both of these sites, the deeper portion of the hole sampled a levee deposit (built by deposition from turbidity currents that spilled out of the channel), whereas the upper portion of the hole sampled distal levee sediments deposited when the adjacent channel was abandoned and inactive. Other channels were active or deposited during sea-level highstands when a reduced amount of sediment reached the fan. The deep levee at Site 932 is thought to be deposited during isotopic Stage 4 (Channel 6), whereas the deep levee at Site 942 was deposited during isotopic Stage 6 (Piper et al., Chapter 39, this volume). The OC:SA ratio of active levee sediments is intermediate between the OC:SA ratios of river and shelf sediments (Fig. 16), but closer to that of river sediments, whereas the OC:SA ratio of the sediments deposited on abandoned levees when other channels were active is closer to that of the present shelf sediments (Fig. 16). This is interpreted to mean that the organic carbon that accumulates in active levee sediments is only partially degraded relative to the modern Amazon River, and thus was probably rapidly delivered to the area with few intermediate burials. In contrast, the sediments that accumulate on abandoned levees have been more degraded. Results of neutral sugars (aldoses) and $\delta^{13} \mathrm{C}$ analyses suggest that these indirect sedi- 

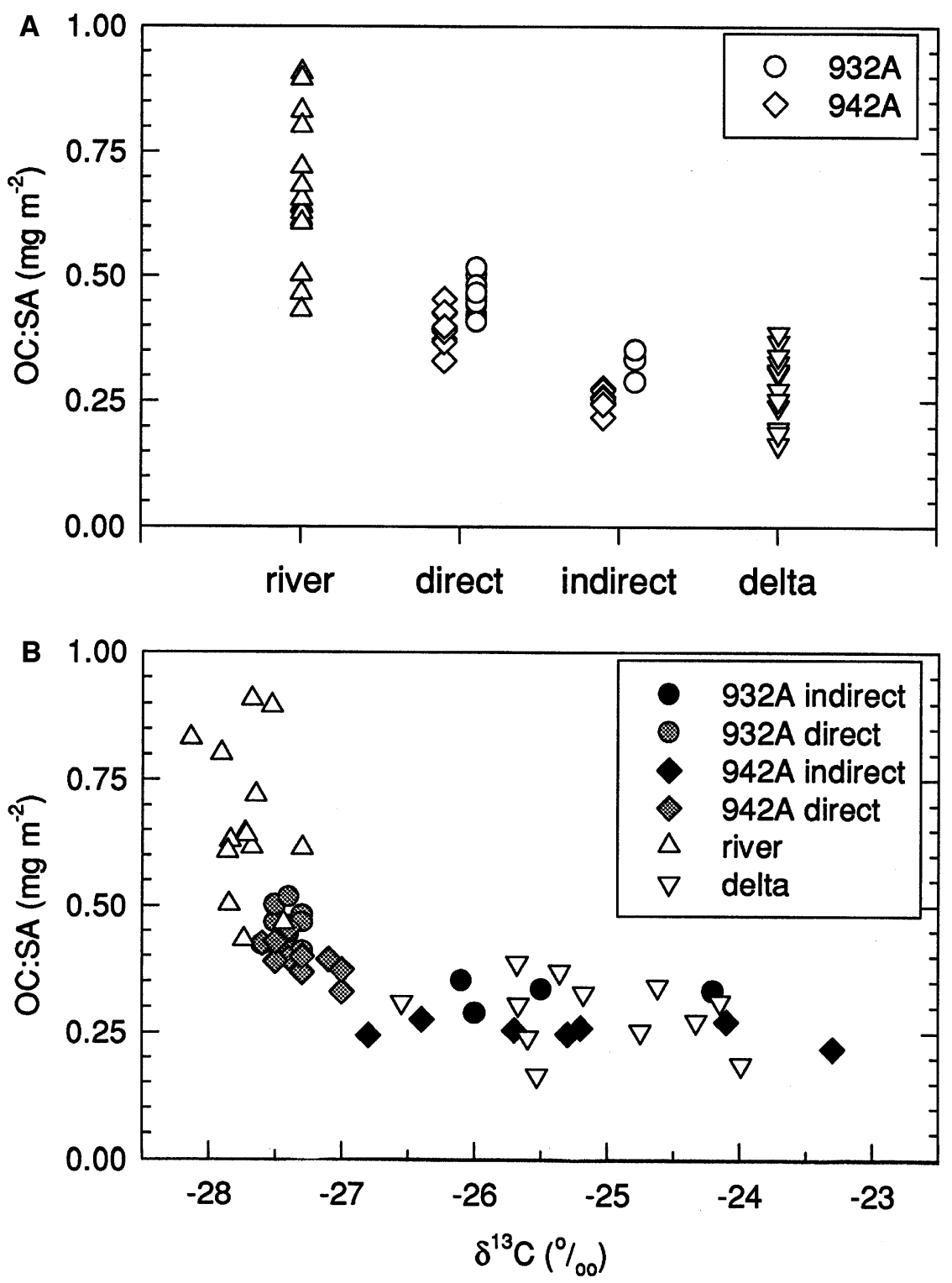

Figure 16. Comparison of organic carbon (OC) to mineral surface area (SA) for Holes 932A and 942A, Amazon River sediment, and Amazon delta sediment (figure from Keil et al., this volume). "Direct" fan deposits corresponding to active (proximal) levees have OC:SA ratios similar to samples suspended in the Amazon River. "Indirect" fan deposits corresponding to sediments deposited on tops of abandoned levees have OC:SA ratios similar to sediments from the modern Amazon delta. Sites of indirect deposition also show higher $\delta^{13} \mathrm{C}$ values suggesting larger percentages of marine organic carbon.

ments are similar to the fine suspended particulate materials carried by the modern Amazon River (consisting of degraded material derived from plants and riverine microorganisms; Keil et al., this volume).

Lignin composition and yield (Goñi, this volume), lipid composition (Hinrichs and Rullkötter, this volume), polycyclic aromatic hydrocarbons (PAHs; Budzinski et al., this volume), phosphorous analyses (Ruttenburg and Goñi, this volume), and carbon isotopes on organic material (Goñi; Schneider et al., both this volume) all support a primary terrestrial origin for the organic matter in the levee deposits. Terrestrial organic matter includes a wide range of compounds, including not only those derived from land plants but also those derived from a wide variety of organisms including soil bacteria, freshwater plankton, and products resulting from the degradation of these compounds.

Goñi (this volume) demonstrates that the lignin composition in active levee sediments is consistent with a mixture of $80 \%-90 \%$ coarse and 10\%-20\% fine fractions of the modern Amazon River, whereas the lignin composition of the distal levee deposits is more similar to the fine fraction alone (Fig. 17). Lignin phenol yields for active levee sediments are also intermediate between the yields of the coarse and fine fractions, but yields for distal levee deposits are below those of the river fine fraction. The decreased lignin phenol yields in distal levee deposits appear to be due to dilution of terrestrial organics with marine organics, and Goñi (this volume) estimates that terrestrial organics account for between $80 \%$ and $15 \%$ of the organic matter based on lignin yields and organic carbon isotopes (Fig. 16B; see also Keil et al., this volume). Lipid composition also varies in response to the local supply of terrestrial organics.

Hinrichs and Rullkötter (this volume) suggest that the ratio of terrigenous wax alcohols to marine fatty acids varies with sedimentation rate and with an increased sedimentation rate corresponding to an increased predominance of terrigenous wax alcohols. PAHs also reveal a strong terrestrial contribution, although some diagenetic processes were also characterized (Budzinski et al., this volume).

Phosphorous is an important component of marine organic matter (C:P ratio 106:1), but is relatively impoverished in terrestrial plants (C:P ratios up to 800:1; Ruttenburg and Goñi, this volume). The C:P ratio of active levee sediments is high, suggesting a terrestrial origin, whereas the C:P ratio of distal levee and highstand deposits is lower, 
Figure 17. Lignin composition for Site 932 sediments (open circles $=$ direct deposits; closed circles $=$ indirect deposits), and composition range for coarse and fine organic matter from the mainstem of the Amazon River $\left(^{*}=\right.$ sample from the LGM; figure from Goñi, this volume; see Goñi, this volume, for discussion).

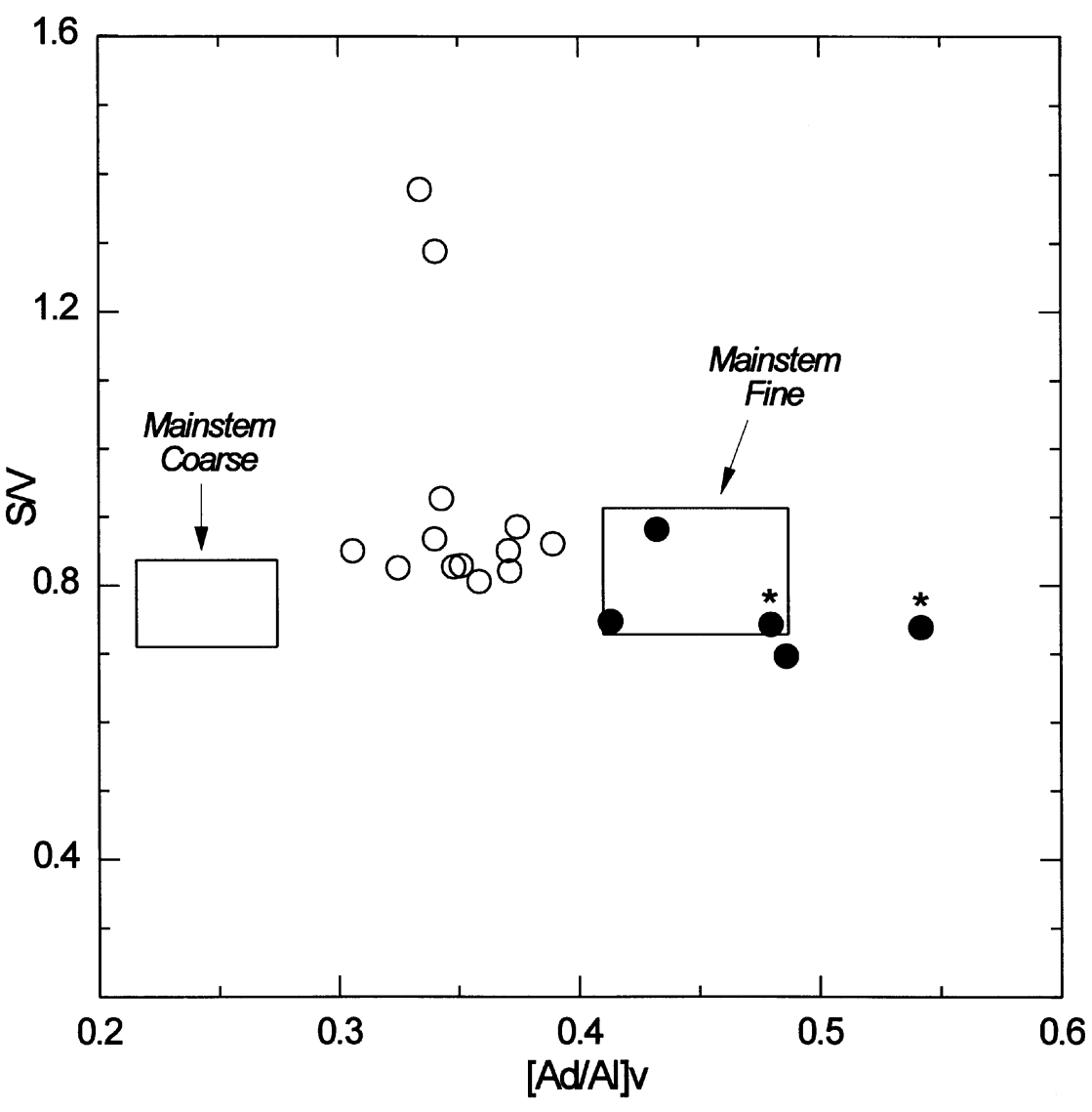

create occasional spikes on the whole-core magnetic susceptibility profiles (Hall et al., Chapter 14, this volume). These spikes sometimes make magnetic susceptibility records difficult to correlate between holes at a site and between sites (Hall, Chapter 15, this volume).

Shipboard analysis of water content and shear-strength profiles at several levee sites $(939,940$, and 944) identified a zone of almost constant water content at $\sim 20-30$ mbsf (17-27 mbsf at Site 939; 2539 mbsf at Site 940; 17-22 mbsf at Site 944). Shipboard observation of hydrotroilite growth patterns (it appears to fill pore space; Shipboard Scientific Party, 1995c) in this depth range suggests that diagenetic growth of hydrotroilite is keeping sediments from compacting normally in this range. This may result in a weakened sediment at the depth where hydrotroilite is converted to other minerals, including greigite, and the weakened sediments could result in slope failure.

\section{Conclusions}

The amount of organic carbon delivered to the Amazon shelf dramatically decreased, and the amount of organic carbon delivered to the deep-water Amazon Fan dramatically increased when the fan was active. This is significant to the global carbon cycle because organic matter deposited on the shelf is intensely reworked and remineralized whereas organic matter deposited on the fan is buried.

Analyses reported on to date suggest that the organic carbon contained in the levees of the active channel during the last glacial period were derived from the Amazon River, with the amount and overall composition of organics in the levee sediments consistent with those transported by the present-day river. The overall similarity in composition between fan organics and the modern river suggests that the river sediments were transported fairly quickly from the river to the fan with few intermediate resuspension events. However, more detailed analyses of the organic matter preserved in fan sediments will be needed to identify possible changes in the character of terrestrial 
organics with time. Sediments that are transported relatively far from the active channel and deposited as distal levee deposits on abandoned levees appear to correspond to the finer-grained component of river sediments that are little altered by diagenesis. These distal levee deposits contain increasing amounts of marine organics as a result of decreased dilution of marine organics by terrestrial organics.

Diagenetic reactions give rise to a number of authigenic minerals in these iron-rich sediments. Hydrotroilite, vivianite, and siderite form within the upper $20 \mathrm{~m}$, and greigite is observed at depth. Diagenetic surfaces may form seismic reflections (e.g., Site 939) and may be zones of preferential weakness leading to slope failure.

\section{GENERAL CONCLUSIONS}

Leg 155 was proposed and drilled because of the potential of continental margin sites to provide high-resolution paleoenvironmental records in addition to important information on sedimentological and geochemical processes. We saw an advantage in drilling where environmental gradients are steep and where the marine and terrestrial records interfinger.

Most of the original predictions have been borne out. Sedimentation rates of up to $25 \mathrm{~m} / \mathrm{k} . \mathrm{y}$. provided extremely high resolution records of oxygen isotopes, magnetic properties, and detrital organic and inorganic material. The fact that these parameters could be correlated between sites and that longer wavelength patterns observed in the high-resolution sites could be recognized in lower sedimentation rate sites (Piper et al., Chapter 39, this volume) is evidence that "reworking" does not seriously hinder paleoenvironmental records in this area. We attribute relatively low amounts of reworking to site selection (reworking is minimized on the topographic elevations of active and inactive levees) to the constructional nature of channel levees, to the relatively small submarine canyon, the primary erosional area, and to the large sediment input. We achieved good rates of recovery, particularly from advanced piston coring (APC), and have a very complete paleoenvironmental record for the past $35 \mathrm{k} . \mathrm{y}$.

Our record of environmental change prior to $\sim 35 \mathrm{ka}$ is less complete. Most of our deeper penetration sites were chosen to meet sedimentological objectives, principally to sample MTDs, deeper levees, and lower fan sands. Site 942 provided an unusually high-resolution record of isotopic Stage 5 (Showers et al.; Schneider et al., both this volume); Site 932 provides a continuous record back to $75 \mathrm{ka}$ (Maslin et al., this volume), and the various deep sites on the middle fan provide a composite section through Stage 7 (Piper et al., Chapter 39, this volume). With the benefit of hindsight, sites could have been chosen to continuously sample the pre-35 ka paleoenvironmental record, at the expense of other objectives.

The steep environmental gradients above the Amazon Fan (Figs. $2,13)$ slowed our progress in arriving at detailed correlations and an age model. Planktonic foraminifer isotopic records vary substantially across the fan, resulting from incursions of warm saline and cold freshwater (Maslin et al., this volume), so that isotopic correlation is not self-evident and must be closely integrated with other information, particularly paleomagnetic data. As a result, most papers in this volume were written without a detailed age model and the benefits of such a model will only be seen in subsequent publications.

The marine record has provided a means of stratigraphic correlation within which the terrestrial detrital record can be assessed. The full benefits of correlations between sites, however, have also not yet been realized in assessing the detrital record on the fan. The fan preserves a record of both high sedimentation rate levees and slower sedimentation rate "hemipelagic" deposition for most time intervals from 10 to $70 \mathrm{ka}$. The high sedimentation rate sections probably contain a detailed record of climatic change on a scale of $10^{2}$ to $10^{4}$ years, through a proxy of sediment grain size or subtle changes in detrital petrology and palynology. At present, only the broad climatic features of the Pleistocene Amazon Basin have been sketched out.
By drilling a wide range of acoustic facies and depositional environments, for which a detailed chronologic correlation is available, the leg has greatly advanced our understanding of the depositional character of deep-sea fan facies and the processes leading to their deposition. Major MTDs were systematically drilled; they appear to be major blocky landslides, largely derived from the continental slope and probably triggered by sublimation of gas hydrates during falling or low sea level.

Studies during Leg 155 have shown that terrigenous continental margin sediments can be successfully cored, with high rates of recovery, despite considerable amounts of sand, provided that sites are carefully selected. Good correlation can be achieved beyond the range of ${ }^{14} \mathrm{C}$ dating, principally using paleomagnetic intensity and orientation data and isotopes of oxygen and carbon preserved in rapidly buried foraminifers. The sediments contain a high-resolution record of paleoclimatic events in the ocean and the adjacent continent. Carefully selected sites provide important information on sediment facies, depositional processes, and diagenetic reactions. High rates of terrigenous sedimentation are not a barrier to solving important paleoenvironmental problems.

\section{ACKNOWLEDGMENTS}

This study simply could not have been done without the Ocean Drilling Program and its international supporters. Special thanks goes to Adam Klaus (Staff Scientist), Gene Pollard (Operations Superintendent), Robert Caldow (Drilling Superintendent), and Captain Ribbens (Master, SEDCO/BP 471), and to their capable staffs. Postcruise publication support and assistance at ODP is also gratefully acknowledged. The shipboard and shore-based scientific party contributed unselfishly to this study and generously provided their initial results, many of which are not summarized here. Participation of RDF in this study was supported by JOI grant JSC-1592 and USSSP grant USSSP-068. This manuscript benefited from reviews by H.W. Posamentier and P. Weimer. This is publication number 1048 of the Marine Sciences Research Center.

\section{REFERENCES}

Absy, M.L., Cleef, A., Fournier, M., Martin, L., Servant, M., Siffedine, A., Ferriera da Silva, M., Soubies, S., Suguio, K., Turcq, B. and Van der Hammen, T., 1991. Mise en evidence de quatre phases d'ouverture de la forêt dense dans le sud-est de l'Amazonie au cours des 60000 dernières années. Première comparaison avec d'autres régions tropicales. C.R. Acad. Sci. Ser. 2, 312:673-678.

Aller, R.C., Blair, N.E., Zia, Q., and Rude, P.D., 1996. Remineralization rates, recycling and storage of carbon in Amazon Shelf sediments. Cont. Shelf Res., 16: 753-786.

Bouma, A.H., Coleman, J.M., Meyer, A.W., et al., 1986. Init. Repts. DSDP, 96: Washington (U.S. Govt. Printing Office).

Caratini, C., Bellet, J., and Tissot, C., 1978. Étude microscopique de la matière organique: palynologie et palynofacies. In Coubas, A., and Pelet, R. (Eds.), Géochimie des sédiments marins profonds, Orgon II, AtlantiqueN.-E. Brésil: Paris (Ed. Cen. Nat. Rech. Sci.), 157-178.

Caratini, C., and Tissot, C., 1976. Campagne Orgon II: Palynologie. Institut de Géodynamique, Université de Bordeau.

CLIMAP Project Members, 1976. The surface of the ice-age Earth. Science, 191:1131-1137.

Colinvaux, P.A., 1989. Forest paleoecology: ice-age Amazon revisited. Nature, 340:188-189.

Damuth, J.E., Flood, R.D., Knowsmann, R.O., Belderson, R.H., Gorini, M.A., 1988. Anatomy and growth patterns of Amazon deep-sea fan as revealed by long-range side-scan sonar (GLORIA) and high-resolution seismic studies. AAPG Bull., 72:885:911

Damuth, J.E., Kowsmann, R.O., Flood, R.D., Belderson, R.H., and Gorini, M.A., 1983. Age relationships of distributary channels on Amazon deepsea fan: implications for fan growth pattern. Geology, 11:470-473.

Driscoll, N., and Karner G., 1994. Flexural deformation due to Aamazon Fan loading; a feedback mechanism affecting sediment delivery to margins. Geology, 22:1015-1018. 
Droz, L., and Bellaiche, G., 1985. Rhône deep-sea fan: morphostructure and growth pattern. AAPG Bull., 69:460-479.

Ertel, J.R., Hedges, J.I., Devol, A.H., Richey, J.E., and Riberio, M., 1986. Dissolved humic substances of the Amazon River system. Limnol. Oceanogr., 31:739-754.

Fairbanks, R.G., 1989. A 17,000-year glacio-eustatic sea level record: influence of glacial melting rates on the Younger Dryas event and deep-ocean circulation. Nature, 342:637-642.

Farrell, W.E., and Clark, J.A., 1976. On postglacial sea level. Geophys. J. $R$. Astron. Soc., 46:647-667.

Flood, R.D., Manley, P.L., Kowsmann, R.O., Appi, C.J., and Pirmez, C., 1991. Seismic facies and late Quaternary growth of Amazon submarine fan. In Weimer, P., and Link, M.H. (Eds.), Seismic Facies and Sedimentary Processes of Modern and Ancient Submarine Fans: New York (Springer), 415-433.

Flood, R.D., Piper, D.J.W., Klaus, A., et al., 1995. Proc. ODP, Init. Repts., 155: College Station, TX (Ocean Drilling Program).

Flood, R.D., Piper, D.J.W., and Shipboard Scientific Party, 1995. Introduction. In Flood, R.D., Piper, D.J.W., Klaus, A., et al., Proc. ODP, Init. Repts., 155: College Station, TX (Ocean Drilling Program), 5-16.

Franzinelli, E., and Potter, P.E., 1980. Petrology, chemistry and texture of modern river sands, Amazon River system. J. Geol. 91:23-39.

Gibbs, R.J., 1967. The geochemistry of the Amazon River system. Part I.The factors that control the salinity and the composition and concentration of the suspended solids. Geol. Soc. Am. Bull., 78:1203-1232.

Hedges, J.I., Clark, W.A., Quay, P.D., Rochey, J.E., Devol, A.H., and Sandos, U.M., 1986. Compositions and fluxes of particulate organic material in the Amazon River. Limnol. Oceanogr., 31: 717-738.

Hedges, J.I., and Keil, R.G. 1995. Sedimentary organic matter preservation: an assessment and speculative synthesis. Mar. Chem., 49:89-115.

Hiscott, R.N., Pirmez, C. and Flood, R.D., in press. Amazon submarine fan drilling: a giant step forward for fan models. Can. J. Sci.

Imbrie, J., Hays, J.D., Martinson, D.G., McIntyre, A., Mix, A.C., Morley, J.J., Pisias, N.G., Prell, W.L., and Shackleton, N.J., 1984. The orbital theory of Pleistocene climate: support from revised chronology of the marine $\delta^{18} \mathrm{O}$ record. In Berger, A.L., Imbrie, J., Hays, J., Kukla, G., and Saltzman, B. (Eds.), Milankovich and Climate (Pt. I), NATO ASI Ser. C., Math Phys. Sci., 126: Dordrecht (Riedel ), 269-305.

Keil, R.G., Tsamakis, E., Fuh, C.B., Giddings, J.A., and Hedges, J.I., 1994. Mineralogical and textural controls on the organic composition of coastal marine sediments: hydrodynamic separation using SPLITT-fractionation. Geochim. Cosmochim. Acta, 58:879-893.

Kronberg, B.I., Nesbitt, H.W., and Lam, W.W., 1986. Upper Pleistocene Amazon deep-sea fan muds reflect intense chemical weathering of their mountainous source lands. Chem. Geol., 54:283-294.

Liu, K.-L., and Colinvaux, P.A., 1988. A 5200-year history of Amazon rain forest. J. Biogeogr., 15:231-248.

Manley, P.L., and Flood, R.D., 1988. Cyclic sediment deposition within Amazon deep-sea fan. AAPG Bull., 72:912-925.

Mayer, L.M., 1994. Surface area control of organic carbon accumulation in continental shelf sediments-a hypothesis. Geochim. Cosmochim. Acta, 58:1271-1284.

Metcalf, W.G., and Stalcup, M.C., 1967. Origin of the Atlantic Equatorial Undercurrent. Deep-Sea Res., 72:4959-4975.

Milliman, J.D., Summerhayes, C.P., and Barretto, H.T., 1975. Quaternary sedimentation on the Amazon continental margin: a model. Geol. Soc. Am. Bull., 86:610-614.

Nesbitt, H.W., MacRaw, N.D., and Kronberg, B.I., 1990. Amazon deep-sea fan muds: light REE enriched products of extreme chemical weathering. Earth Planet. Sci. Lett., 100:118-123.

Nilson, T.H., Imperato, D.P., and Moore, D.W., 1994. Reservoir geometry and architecture of productive Upper Cretaceous mud-rich and sand-rich submarine fan systems, Sacramento Basin, California. In Weimer, P., Bouma, A.H., and Perkins, B.F. (Eds.), Submarine Fans and Turbidite Systems. Sequence Stratigraphy, Reservoir Architecture and Production Characteristics: Gulf Coast SEPM Res. Conf., 15:269-280.

Nittrouer, C.A., and DeMaster, D.J., 1986. Sedimentary processes on the Amazon continental shelf: past, present and future research. Cont. Shelf Res., 6:5-30.
Nittrouer, C.A., Kuehl, S.A., Sternberg, R.W., Figueiredo, A.G. Jr., and Faria, L.E.C., 1995. An introduction to the geological significance of sediment transport and accumulation on the Amazon continental shelf. Mar. Geol., 125:177-192.

Normark, W.R., Posamentier, H., and Mutti, E., 1993. Turbidite systems: state of the art and future directions. Rev. Geophys., 31:91-116.

Peteet, D., 1986. Late Quaternary vegetational changes and climatic history of the montane and lowland tropics. In Rosenzweig, C., and Dickinson, R.D. (Eds.), Report OIES-2: Boulder, CO (Off. Interdiscipl. Earth Stud., Univ. Center for Atmos. Res.), 72-75.

Philander, S., and Pacanowski, R., 1986. A model of the seasonal cycle in the tropical Atlantic Ocean. J. Geophys. Res., 91:192-206.

Picaut, J., Servain, J., Lecomte, P., Seva, M., Lukas, S., and Rougier, G., 1985. Climatic Atlas of the Tropical Atlantic Wind Stress and Sea Surface Temperature 1964-1979: Honolulu (Univ. of Hawaii).

Pirmez, C. 1994. Growth of a submarine meandering channel-levee system on the Amazon Fan [Ph.D. dissert.]. Columbia Univ., New York.

Pirmez, C., and Flood, R.D. 1995. Morphology and structure of Amazon Channel. In Flood, R.D., Piper, D.J.W., Klaus, A., et al., Proc. ODP, Init. Repts., 155: College Station, TX (Ocean Drilling Program), 23-45.

Posamentier, H.W., Erskine, R.D., and Mitchum, R.M., Jr., 1991. Models for submarine fan deposition within a sequence-stratigraphic framework. In Weimer, P., and Link, M.H. (Eds.), Seismic Facies and Sedimentary Processes of Modern and Ancient Submarine Fans: New York (Springer), $127-136$

Posamentier, H.W., and Allen, G.P., 1993. Variabililty of the sequence stratigraphic model: effects of local basin factors. Sed. Geol., 86:91-109.

Posamentier, H.W., and Vail, P.R., 1988. Eustatic controls on clastic deposition. II: Sequence and systems tract models. In Wilgus, C.K., Hastings, B.S., Ross., C.A., Posamentier, H.W., Van Wagoner, J., and Kendall, G.C. St. C. (Eds.), Sea-Level Changes: An Integrated Approach. Special Publications-Soc. Econ. Paleontol. Mineral., 42:125-154.

Reading, H.G., and Richards, M., 1994. Turbidite systems in deep-water basin margins classified by grain size and feeder system. AAPG Bull., 78: 792-822.

Richardson, P., and Walsh, D., 1986. Mapping climatological seasonal variations of surface currents in the tropical Atlantic using ship drifts. J. Geophys. Res., 91:537-550.

Rind, D., and Peteet, D., 1985. Terrestrial conditions at the last glacial maximum and CLIMAP sea-surface temperature estimates: are they consistent. Quat. Res., 24:1-22.

Shipboard Scientific Party, 1995a. Leg synthesis. In Flood, R.D., Piper, D.J.W., Klaus, A., et al., Proc. ODP, Init. Repts., 155: College Station, TX (Ocean Drilling Program), 17-21.

Shipboard Scientific Party, 1995b. Site 934. In Flood, R.D., Piper, D.J.W., Klaus, A., et al., Proc. ODP, Init. Repts., 155: College Station, TX (Ocean Drilling Program), 241-272.

Shipboard Scientific Party, 1995c. Site 939. In Flood, R.D., Piper, D.J.W., Klaus, A., et al., Proc. ODP, Init. Repts., 155: College Station, TX (Ocean Drilling Program), 437-461.

Shipboard Scientific Party, 1995d. Site 942. In Flood, R.D., Piper, D.J.W., Klaus, A., et al., Proc. ODP, Init. Repts., 155: College Station, TX (Ocean Drilling Program), 537-567.

Shipboard Scientific Party, 1995e. Site 946. In Flood, R.D., Piper, D.J.W., Klaus, A., et al., Proc. ODP, Init. Repts., 155: College Station, TX (Ocean Drilling Program), 657-693.

Showers, W.J., and Angle, D.G., 1986. Stable isotope characterization of organic carbon accumulation on the Amazon continental shelf. Cont. Shelf Res. 6:227-244.

Showers, W.J., and Bevis, M., 1988. Amazon Cone isotopic stratigraphy: evidence for the source of the tropical meltwater spike. Palaeogeogr. Palaeoclimatol., Palaeoec., 64:189-199.

Stacey, M.W., and Bowen, A.J., 1988. The vertical structure of density and turbidity currents: theory and observation. J. Geophys. Res., 93:35283542.

Stow, D.A.V., Howell, D.G., and Nelson, H.C., 1985. Sedimentary, tectonic, and sea-level controls. In Bouma, A.H., Normark, W.R., and Barnes, N.E. (Eds.), Submarine Fans and Related Turbidite Systems: New York (Springer-Verlag), 15-22. 
Stute, M., Schlosser, P., Clark, J.F., and Broecker, W.S., 1992. Paleotemperatures in the Southwestern United States derived from noble gases in ground water. Science, 256:1000-1003.

Vail, P.R., Audemard, F., Bowman, S.A., Eisner, P.N., and Perez-Cruz, G., 1991. The stratigraphic signatures of tectonics, eustacy, and sedimentology - an overview. In Einsele, G., Ricken, W., and Seilacher, A. (Eds.), Cycles and Events in Stratigraphy: Berlin (Springer), 617-659

Vail, P.R., Mitchum, R.M., Jr., and Thompson, S., III, 1977. Seismic stratigraphy and global changes of sea level, Part 3. Relative changes of sea level from coastal onlap. In Payton, C.E. (Ed.), Seismic Stratigraphy: Applications to Hydrocarbon Exploration. AAPG Mem., 26:63-81.
Weimer, P., 1989. Sequence stratigraphy of the Mississippi Fan (Plio-Pleistocene), Gulf of Mexico. Geo-Mar. Lett., 9:185-272.

Weimer, P., 1990. Sequence stratigraphy, facies geometries and depositional history of the Mississippi Fan, Gulf of Mexico. AAPG Bull., 74:425-453.

Date of initial receipt: 20 June 1996

Date of acceptance: 15 October 1996

Ms 155SR-246 